\title{
Demand for the quality conservation of Venice, Italy, according to different nationalities
}

\author{
Silva MARZETTI DALL'Aste BRANDOLINI \\ Department of Economics, University of Bologna, Piazza Scaravilli 2, 40126 Bologna, \\ Italy. E-mail: silva.marzetti@unibo.it. (Corresponding author.) \\ MARTA DISEGNA \\ School of Economics and Management, Free University of Bozen-Bolzano, Italy.
}

This paper focuses on visitor demand for the quality conservation of Venice according to different nationalities. The vast majority of visitors to Venice are foreigners (both tourists and day-visitors) who come from all over the world. In this research they are mainly categorized as non-Italian Europeans or non-Europeans. A specific theoretical model, in which quality conservation is provided publicly and also privately through donations, is presented for nationals and for foreigners. The data are obtained from a contingent valuation survey carried out in Venice, the aim of which was to estimate visitors' willingness to donate (WTD) to the Venice flood defence programme. Demand functions are estimated by applying a twostage regression model. The authors show that the majority of visitors are willing to donate. On average, Italians and nonEuropeans would donate more than non-Italian Europeans. As expected, these visitor categories have different mean WTD and different behavioural functions which are affected by attitudinal and economic variables. Bequest value is the main donation motive. Those who identify this as a donation motive, on average, state the highest WTD and the highest degree of certainty to donate. This result seems to confirm empirically the validity of the sustainable development principle applied to the management of Venice as a cultural tourist site.

Keywords: cultural goods valuation; donation theory; foreign tourism; sustainable tourism; total economic value; Venice

JEL classification: $\mathrm{H} 41 ; \mathrm{Q} 01 ; \mathrm{Q} 26$

EU support through RTD project DELOS, contract EVK3-CT-2000-00041, is gratefully acknowledged. Thanks are due to the Consorzio Venezia Nuova for Figure 2 and other material provided, Alberto Lamberti for the engineering aspects of the defence project, Barbara Zanuttigh for Figures 1 and 3 and Carlo Barbanti for Figure 3. Finally, the authors thank the referees whose comments and suggestions improved this paper. The survey instruments and further data description are available upon request. 
Venice was designated a World Heritage Site by the United Nations Education, Scientific and Cultural Organization (UNESCO) in 1987 for its historical and architectural characteristics. This Italian town is a wonder whose supply cannot be increased. Its different architectural styles, such as Byzantine, Gothic, early Renaissance and late Renaissance architecture, form a very pleasant contrast and attract numerous visitors from all over the world. It is considered the only town in the world in which a medieval citizen returning today would still be able to find his or her way around (Cellerino, 1998). According to the new property rights approach (Mitchell and Carson, 1989), the world community - residents, tourists, day-visitors and people who have never visited and will never visit Venice - has a sort of 'common property right' over the city.

Venice is subject to flooding (high water phenomenon), which is becoming more frequent. Because 'the greatest fear is that it might finally be engulfed by the sea' (Ghetti and Batisse, 1983, p. 3), it must be artificially defended from such an event. As regards coastal sites, the European Union (EU) recommends that Member States should manage them according to integrated coastal zone management (ICZM). ${ }^{1}$ The EU recognizes that it is essential to implement an environmentally sustainable, economically equitable, socially responsible, and culturally sensitive management of coastal zones', and that the strategic approach for coastal management is based on 'appropriate and ecologically responsible coastal protection measures, including protection of coastal settlements and their cultural heritage', and on 'adequate accessible land for the public, both for recreational purposes and aesthetic reasons' (European Parliament and European Council, 2002). This approach admits that stakeholders are encouraged to contribute actively to the conservation of coastal resources for present and future generations.

The amount of public funds required for the implementation of the Venice defence programme according to the ICZM is considerable. In order to ascertain whether stakeholders are willing to contribute to the quality conservation of Venice, a contingent valuation (CV) survey was carried out in 2002 within the DELOS (Environmental Design of Low Crested Coastal Defence Structures) research project, EU Fifth Framework Programme, 1998-2002 (Marzetti, 2003). DELOS is a multidisciplinary research project which aims to establish, from engineering, ecological and socio-economic points of view, guidelines for designing sustainable low crested structures (LCS) ${ }^{2}$ to defend the coast from erosion and flooding (www.delos.unibo.it; Burcharth et al, 2007).

Although for Venice, the relevant population is the world community, the focus is on a particular category of stakeholders - visitors (nationals and foreigners). Foreigners constitute more than $80 \%$ of the total visitors per year, often travelling long distances to see the historical centre of Venice. This is the first research study to collect data to ascertain: (1) whether visitors, distinguished by nationality, are willing to contribute to the conservation of Venice in a hypothetical condition of scarcity of public funds; and (2) their demand functions for Venice's conservation. The payment vehicle is a yearly donation. Since visitors may be willing to donate for different reasons, in this study the reference is mainly to non-use benefits, defined here as the values that people derive from Venice independently of its present use. More specifically, they may be willing to donate for the benefit of future generations (bequest value), for the mere existence of Venice (existence value), and for the benefit 
of others of the present generation (altruism). Furthermore, risk-adverse people may be willing to donate something more than the mere value of their expected consumer surplus for its conservation (option value).

Some of the data collected in the survey have already been published in Marzetti (2003), Marzetti and Lamberti (2003), Polomè et al (2005) and Marzetti and Disegna (2009). Although the data refer to 2002, we have decided to analyse them in greater depth according to different nationalities, since it seems to us that today they still retain their scientific interest, for various reasons: (1) since Venice is a historical and cultural town to be conserved, the main reasons why it is visited cannot change as time goes by, because they depend on these permanent characteristics; (2) the implementation of the conservation project of Venice is still in progress; (3) from 2002 to 2009 the proportion of foreigners and nationals did not change significantly, nor did their preferences about accommodation (see the section below, 'Tourism in Venice'); and (4) from the theoretical point of view, given the great number of foreign visitors, these data suggested that two donation models should be built by distinguishing nationals from foreigners. ${ }^{3}$

Since visitors to Venice not only pay different travel costs, but also have different cultures and habits, it is expected that according to nationality they may have different preferences about Venice's conservation and therefore their willingness to donate and demand functions may be different. In particular, the available data permit us to obtain interesting results by distinguishing respondents into Italians, non-Italian Europeans and non-Europeans. In addition, since foreigners are not only tourists but also day-visitors, this research also provides data about foreign day-visitors, distinguished according to nationality. Therefore, after a brief presentation of the defence project and of tourism characteristics in Venice, the main results of previous studies about cultural sites are presented. The contingent valuation method (CVM), the survey design and the sampling design are described; in particular, the use of a donation as payment vehicle (which has to be used with caution) is justified. Specific utility models for donation by nationals and by foreigners are presented. Descriptive statistics are computed. After describing the statistical model, visitors' donation demands are presented. Our conclusions highlight the fact that visitors are willing to donate, and that, on average, Italians and non-Europeans would donate more than non-Italian Europeans. In addition, as expected, these visitor categories have different behavioural functions.

\section{The flood defence project}

Venice is situated in a lagoon (the Lagoon of Venice) in the Northern Adriatic Sea. It consists of different areas, such as Venice-Burano-Murano, Mestre, Marghera, Lido and Pellestrina Islands. Residents number about 270,000, about 60,000 of whom live in the historical centre. The lagoon is almost $50 \mathrm{~km}$ long and $10 \mathrm{~km}$ wide. It is a fragile environment, created by the balancing of forces coming from land and sea, that houses the port of Marghera (one of the most important industrial ports in Italy), a modern industrial zone, an airport and numerous fish farms. Since Venice is built on 118 islands, which are divided by 160 canals and connected by about 400 bridges, Venetians greatly depend on boat traffic for supplies. 


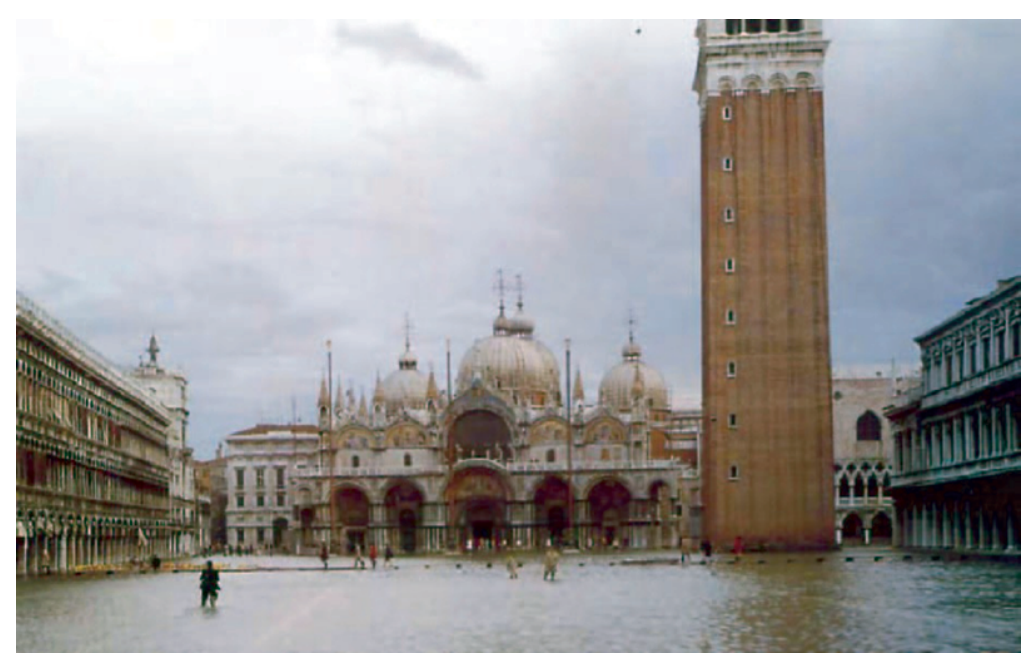

Figure 1. St Mark's Square flooded.

The survival of Venice and its lagoon depend on water exchange, which is regulated by tides. Situations of acque alte (high waters), characterized by a lagoon water level higher than the normal tide-level, are increasingly frequent. Acque alte are mainly due to a rise in sea-level, the sinking of Venice $(23 \mathrm{~cm}$ lower than it was at the beginning of the 20th century) and the increasing height and duration of tidal storm surges. More specifically, with respect to the sea level, Venice is built on different levels. Therefore, when the height of the tide is $100 \mathrm{~cm}$ there is about $20 \mathrm{~cm}$ of water in more than $5 \%$ of public walkways, and part of St Mark's Square and its monuments are flooded (Figure 1); when the tide reaches more than $130 \mathrm{~cm}, 62 \%$ of Venice is flooded (Ghetti and Batisse, 1983; Cellerino 1998). In addition, there is a greater risk of extreme events, such as the high tide of $194 \mathrm{~cm}$ in 1966 where Venice was submerged by about $1 \mathrm{~m}$ of water. In this condition, economic activities, buildings and monuments are endangered, and residents and visitors suffer discomfort.

National, regional and local governments are engaged in the defence programme to conserve Venice, which consists of different kinds of interventions (General Plan of Interventions, Law 139/92 and Law 798/84). We mention the defence and rebalance of the morphological and hydrodynamic system of the lagoon, the defence of buildings, the elevation of floors and pavements, the protection of the natural barriers (coastal strips) of Pellestrina and Lido islands from sea erosion by the building of artificial beaches defended by LCS (as shown in Figure 2) and the MOSE (Modulo Sperimentale Elettromeccanico) project. On behalf of the Ministry of Infra-structures and Transport-Venice Water Authority, the Consorzio Venezia Nuova is responsible for the implementation of MOSE, which started in May 2003 (Italian Law 798/ 84) and which involves the building of 78 mobile metal floodgates for the temporary closure of the three mouths of the lagoon of Venice, as shown in Figure 3. 


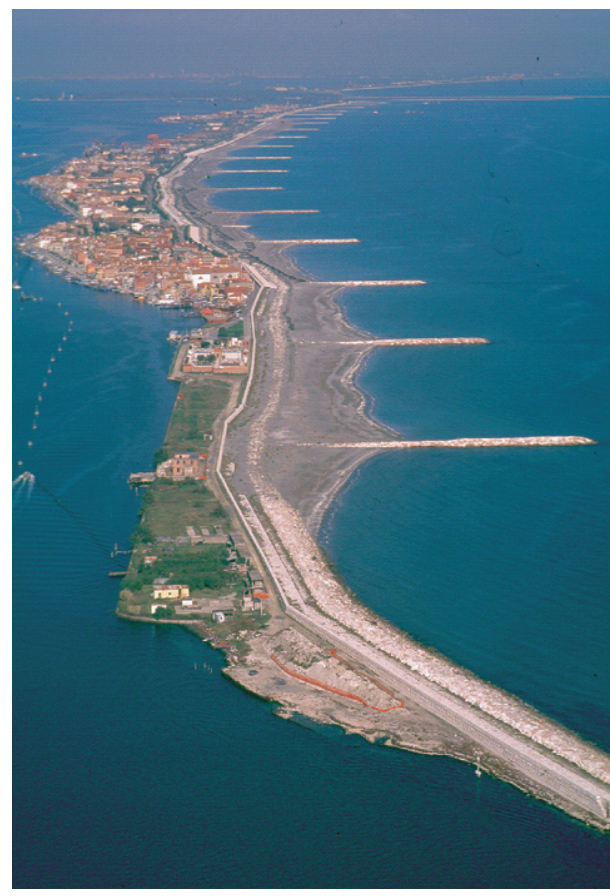

Figure 2. Pellestrina artificial defence.

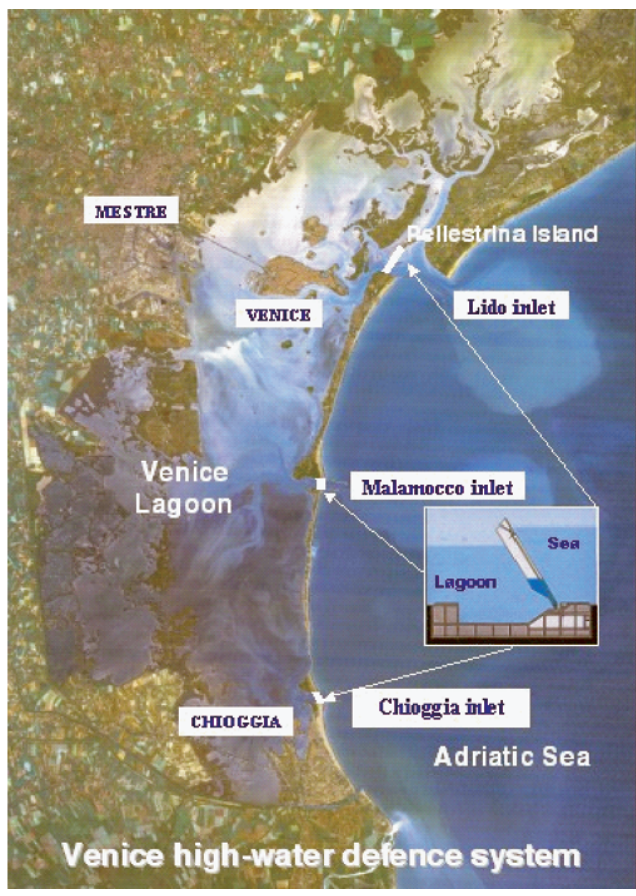

Figure 3. The Modulo Sperimentale Elettromeccanico (MOSE).

The cost of the implementation and maintenance of this complex defence system is very high. This programme has been funded mainly by the Italian government through ordinary fiscal entries. In particular, the total cost of the implementation of MOSE is now estimated to be more than $€ 5$ billion, and its maintenance costs about $€ 9$ million per year (SAL.VE, 2008). To date, $60 \%$ of this project has been implemented, and about 700 people with a fleet of 100 boats are working towards its completion, scheduled for 2014. This CV exercise was justified by the awareness that public funds may become scarce in the future, while the implementation of the Venice defence programme and its maintenance are considered a priority.

\section{Tourism in Venice}

The tourism sector, in particular international tourism, is a very well developed economic activity in Venice. Tourism is defined as the activities of persons travelling to and staying in places outside their usual environment for not more than one consecutive year for leisure, business and other purpose' (WTO, 1995). Visitors are categorized as tourists or day-visitors. Tourists are defined as people who stay in a site for at least 24 hours and not more than one year, while dayvisitors are people who visit a site but do not sleep in it. Since we are interested in finding out how many visitors (tourists and day-visitors) are willing to 
Table 1. Tourist arrivals and day-visitors to Venice - official data for 2002, 2007 and 2009.

\begin{tabular}{lrrr}
\hline Visitor category & \multicolumn{1}{c}{2002} & \multicolumn{1}{c}{2007} & $2^{2009^{\mathrm{a}}}$ \\
Tourist arrivals & $2,721,656$ & 3.626 .853 & $3,405,115$ \\
Italians & 458,828 & 574,270 & 588,798 \\
Foreigners & $2,261,828$ & 3.052 .583 & $2,816,317$ \\
Day-visitors & $11,117,142$ & $18,140,106$ & \\
False day-visitors & $5,332,068$ & $8,732,669$ & \\
Other day-visitors $^{\mathrm{b}}$ & $5,744,074$ & $9,407,437$ & \\
Total arrivals & $13,838,798$ & $21,766,959$ & \\
\hline
\end{tabular}

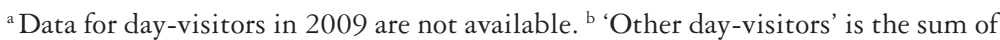
true day-visitors, day-visitors 'passing through' and indirect day-visitors.

contribute per year to Venice's conservation and not per visit to its historical centre, the focus is on yearly arrivals and not on night-stays as regards tourists to Venice.

Visitors' arrivals are officially recorded by the local public authorities. Over the last 50 years they have continuously increased. In particular, as shown in Table 1, they increased from more than 13.5 million in 2002 to more than 21.5 million in 2007.

\section{Tourist arrivals}

Tourists to Venice are mainly foreigners who tend to find accommodation in the historical centre, Mestre-Marghera (Venice mainland) and Lido Island. In order to gain an idea of the dimension and evolution of Venice's tourism we present official data for 2002 (the year of the survey), 2007 (the year of the most recently available data about day-visitors) and 2009 (the most recently available official data about tourists). Table 1 shows that total tourist arrivals in Venice (intended as Venice Municipality) increased from about 2.7 million in 2002 to about 3.4 million in 2009 (Comune di Venezia, 2010).

Tourists are more numerous in summer. In general, about $80 \%$ stay in hotels, while the rest stay in rented flats, rooms or campsites. They stay on average just over two days and more specifically they stayed for 2.22 days in 2002 and 2.46 in 2009. Night-stays (tourist arrivals multiplied by mean night stays) increased from $6,033,325$ in 2002 to $8,445,911$ in 2009. Among those who stay in hotels there has been an increase in the quality demanded, since the number staying in five star hotels has increased, while the number staying in one and two star hotels has decreased (Comune di Venezia, 2010; CESDOC, 2008 and 2010).

From the data presented in Table 1 we see that, in the three years considered, the proportion of foreigners $(83.72 \%$ in $2002,84 \%$ in 2007 and $82.70 \%$ in 2009) out of the total number of tourists has not changed significantly. Regarding Europe, in general tourists mainly come from Germany, the UK and France; regarding the Americas, they mainly come from the USA and Canada; while for the other continents they mainly come from Japan and Australia. More 
than $80 \%$ of the total number of foreign tourists prefer to stay in hotels, and more than $80 \%$ of these prefer the historical centre (COSES, 2003; CESDOC, 2008, 2010). The majority of Japanese and Chinese prefer to find accommodation in Mestre-Marghera. Those who stay in the historical centre and on Lido Island stay on average approximately 2.5 days, while those who stay in Mestre-Marghera stay less than 2 days.

Italian tourists make up less than $20 \%$ of the total number of tourists (16.28\% in 2002 and $17.30 \%$ in 2009). They come mainly from the Lombardy and Lazio regions. A lower percentage of Italian tourists prefer to stay in the historical centre (45.98\% in 2002 and 52.2\% in 2009). In general, those who stay in the historical centre and on Lido Island stay on average about 2.5 days, while those who stay in Mestre-Marghera stay slightly less time. Like foreigners, the great majority of Italian tourists prefer to stay in hotels (COSES, 2003; CESDOC, 2008, 2010).

\section{Day-visitors}

Day-visitors are more numerous than tourists and are both Italians and foreigners. Local authorities responsible for recording visitor flows to Venice are interested in knowing not only the number of those who visit Venice and do not sleep there, but also their specific characteristics: experience has shown that they can be distinguished according to different situations. Therefore, they are officially classified into (and data are provided according to) the following categories: (1) 'false day-visitors', defined as those whose aim is to visit Venice's historical centre and who do not stay in Venice but in a nearby town or resort mainly in order to save money on accommodation; and (2) 'other day-visitors', which include those who exclusively visit the historical centre of Venice and return home the same day (also classified as 'true' day-visitors), those who are on holiday in another site in the same region (such as Cortina d'Ampezzo) or the nearby regions (such as Emilia-Romagna) and take the opportunity to visit Venice ('indirect' day-visitors) and those who are going on holiday in another site and stop briefly in Venice (day-visitors 'passing through').

Since day-visitors do not stay in hotels or other accommodation structures in Venice, they are estimated by counts at the main terminals of the town: that is, by considering bus arrivals in the limited traffic zones, arrivals in car parks and garages and boat tickets sold. The data thus obtained are managed in the awareness that double counting has to be avoided (COSES, 2009). We found official data for 2002 and 2007. Table 1 shows that there were estimated to be more than 11 million day-visitors in 2002, and more than 18 million in 2007 (http://pianogestionelagunavenezia.net/turismo.html). In particular, in 2002 and 2007 'false day-visitors' were just over 5 million, while 'other dayvisitors' ranged from more than 8.5 million to more than 9 million. We did not find official data about day-visitors distinguished according to nationality for the years considered in Table 1. We know only from 1996 data that true day-visitors are mainly Italians; while foreigners are mainly false and indirect day-visitors (COSES, 2003). Our CV research provides further data about their nationalities, which are presented below in the section on descriptive statistics. 


\section{Previous literature}

The contingent valuation method $(\mathrm{CVM})$ is officially recommended as a valuation technique for water resources in the USA and in the UK. Arrow et al (1993) established general guidelines for estimating non-use values through CVM. As regards cultural goods in general, Navrud and Ready (2002) and Pearce et al (2002) summarized the state of the art about this research field. In particular, in Navrud and Ready (2002) a certain number of studies are described in detail in order to make the reader aware that cultural goods have different characteristics, and that the policies for and the benefits from their conservation are also different. Among these, Pearce et al (2002) present an overview of 27 surveys, fairly heterogeneous as regards the survey design, in order to show some consistent findings that emerge from their results. It is highlighted that the most used CVM payment vehicles are taxes, donations and fees, and that respondents are generally willing to pay for the conservation of cultural goods, thus showing that their loss is undesirable. Noonan's (2003) article, instead, presents a statistical view of the CVM literature about cultural goods by using data from 65 studies (129 different willingness to pay estimates) and the results of the estimate of some meta-regression models which show that different payment vehicles are not significant predictors of WTP.

With regards to cultural and historical cities, recognized as heritage sites by UNESCO, we found only one published CVM study by Carson et al (2002) about the city of Fes Medina in Morocco, one of the largest medieval cities in the world. Fes is an important religious centre for the Islamic world. Its preservation and restoration project is a comprehensive strategy in order to retain its historic character and economic vitality. Benefits from the implementation of this project are estimated through a dichotomous choice (DC) question, which is asked of foreign visitors to Morocco, categorized as visitors to Fes or non-visitors to Fes. The payment vehicle is a conservation fee, to be paid when registering at the hotel in Fes, and a departure fee when non-visitors to Fes leave Morocco. The lower bound on the sample mean is estimated to be about US $\$ 70$ for visitors to Fes and US $\$ 31$ for non-visitors to Fes, while the median is between US $\$ 38 / 43$ and US $\$ 22 / 25$, respectively.

The characteristics of the Fes Medina case study are very different to that of Venice; its results cannot be used for a benefit transfer exercise about the case-study of Venice (Desvousges et al, 1992). Therefore, a specific CVM survey was carried out in order to estimate the value of benefits provided by the implementation of the defence project described above.

\section{The contingent valuation method}

Through a questionnaire survey, CVM creates a hypothetical market for quality conservation, where the willingness to pay (WTP) represents its value. With regards to $\mathrm{CV}$ methodology and philosophy, we refer the reader to the extensive literature (see, in particular, Mitchell and Carson, 1989).

For our purposes, we highlight only that this method requires the specification of a payment vehicle, which can be coercive (tax, daily fee) or voluntary (donation, gift) and that respondents may react in different ways to them. Their 
acceptability and credibility are important for the success of the survey. According to Pearce et al (2006, pp 111-114), with regards to the choice of the payment vehicle, 'a simple guideline is to use the vehicle which is likely to be employed in the real world decision'. In other words, this choice depends on the good being studied and the context in which it is provided.

With regards to the evaluation question format, which one of the different formats yields the most accurate estimates is still an open issue. In the literature much attention has been paid to the open-ended (OE) format and the dichotomous choice (DC) format. What is more, the choice of one format over another depends on the specific situation which characterizes each case-study, because both of them have advantages and disadvantages. We highlight that the DC format yields a less accurate estimate of the $\mathrm{WTP}^{4}$ than the OE format, since it only provides information on the bounds of the expected WTP and not on the maximum WTP. In addition, even if the DC question avoids extreme responses because the choice of bids is made by researchers who conceive the valuation exercise, and even if the OP response format may lead to extreme responses, experience shows that the DC method in general provides higher estimates than the OE format (Noonan, 2003). Furthermore, in a DC question respondents may be affected by the bid offered, since they may be unsure about their actual WTP. Nevertheless, this anchoring bias seems not to occur when the bid is quite low, as highlighted by Bamber and Khoury (1999, p 192) who find 'that the actual bid levels were independent of the initial bid level when the latter was less than $£ 10$ '.

\section{Survey design}

The CVM survey on the Venice defence programme was carried out in 2002, from 26 August to 8 September, a period when the number of visitors is among the highest. A random sample of 1,000 visitors to Venice, aged 18+, was chosen. Each face-to-face interview took 10-15 minutes. Anonymity was guaranteed. Interviews were carried out by a market research firm in Italian for nationals and in English for foreigners.

\section{The specific payment vebicle}

The payment vehicle is a yearly donation. Although a donation may encourage free-riding, at the survey time its use was justified by the specific Venice situation. The Italian government was unwilling to increase the fiscal pressure, since it was already quite high (it was estimated to be $41.6 \%$ of gross domestic product [GDP]). Therefore, an extra tax would not have been acceptable or credible for national respondents. In addition, Venice is visited by a large number of foreigners who are non-tax payers in Italy. They can pay a tourist tax, however, this payment vehicle was rejected since it was abolished in Italy in 1989 in order to boost the tourist sector. Furthermore, with regards to a fee or ticket, visitors who arrive in Venice by bus already pay an entrance fee (http://www.asmvenezia.it), and those who use public motor boats (vaporetti) also pay a higher ticket price than residents (http://www.actv.it). Thus, respondents may have been against paying a further fee or ticket and behaved strategically. 
In this situation, a donation to an unspecified non-profit agency created under the aegis of the public authority responsible for the project implementation was considered a credible and acceptable payment vehicle for contributing to the conservation of Venice.

\section{Questionnaire}

In its final wording, the questionnaire is divided into five parts. After an introduction, providing a brief explanation of the survey's purpose, the first part contains preliminary questions regarding the respondent's residence, means of transport and whether he or she is a tourist or a day-visitor. The second part is concerned with the respondent's recreational activities in Venice and their frequency of visits to Venice. The third part investigates the respondent's attitudes towards historical and cultural goods. More specifically, a respondent is asked the main reason why cultural heritage sites have to be protected in general (such as option value, bequest value, existence value, good cause), if he or she is visiting other Italian and foreign artistic towns, if $s /$ he is a member of any cultural conservation organization and how much money s/he spends on a voluntary basis each year for cultural heritage protection.

The heart of the questionnaire is the fourth part, which includes the evaluation questions. In order to reduce the risk of a hypothetical willingness to donate (WTD) higher than the real one and to obtain a more accurate estimate of the mean WTD, the 'modified double referendum format' is used, which is a combination of a DC question followed by an OE question (Schechter et al, 1998). Respondents are first made aware that the defence programme (shown in Figures 2 and 3) is very expensive and asked if they are in favour of or against its implementation. Second, after having stressed that public funds may become scarce, ${ }^{5}$ they are asked:

(1) 'Would you be willing to donate, to a non-profit agency, €1 per year to cover the cost of the flood and coastal defence programme whose aim is to prevent a loss of the current level of quality conservation of the historical and cultural heritage of Venice? Remember that any money spent on this project cannot be spent elsewhere and that there are many other causes to contribute to.'

We emphasize that, even if the usual rule of thumb for bid design is to divide the sample into a certain number of sub-samples and to offer to each of them a different bid value, the same bid is offered to all respondents in this CV exercise. This bid is in line with some real donation campaigns in Italy for collecting funds for other good causes, in which $€ 1$ is requested as a minimum donation. It is so low that anchoring bias may not occur (Bamber and Khoury, 1999). In addition, respondents are placed in the same condition about the valuation question. If respondents answer yes to the first valuation question, they are also asked:

\section{(2) 'Would you give a higher donation?'}

If the answer is still yes, the following OE question is asked: 
(3) 'What would be your maximum donation?'

Respondents willing to donate are also asked their first donation motive and their second donation motive from the following: (a) option value; (b) altruism; (c) bequest value; (d) existence value; (e) good cause; and (f) 'other motive', to be specified by respondents, such as 'warm glow' (Andreoni, 1989).

In order to validate the empirical result by understanding whether the stated WTD is different from the true WTD (hypothetical bias), on a scale from 0 to 100 , each respondent willing to donate is also asked if he or she is sure that he or she would actually donate the amount declared (Barrens et al, 2002). This value represents an individual probabilistic assessment of visitors' future behaviour which permits identification of inconsistent respondents to the donation question. We call this value the individual degree of certainty to donate' the amount stated. Champ et al (1997) find that there is a close correspondence between those who state they are certain to donate and those who actually donate. Furthermore, in order to confirm respondents' unwillingness to donate, those who answer 'no' to question (1) are asked:

'Are you sure you wouldn't give any money if you were really asked?'

If the answer is 'no' (that is, a respondent is not sure that he or she would not donate), questions (1)-(3) are still asked. Finally, respondents unwilling to donate are asked for their non-donation motive.

The fifth part is about respondents' socio-economic characteristics. In particular, with regards to household net income per year, in order to reduce the number of non-responses if the exact amount of income is asked and to facilitate respondents who do not know the exact current income of their family, a list of 10 income categories was established and shown to interviewees: $€ 1-10,000$; €11,000-15,000; €16,000-20,000; €21,000-25,000; €26,00030,000; €31,000-35,000; €36,000-40,000; €41,000-45,000; €46,000-50,000; and $€ 51,000+$.

\section{How to avoid response effects}

To enhance the reliability of the CVM results, careful attention was paid to reducing and possibly avoiding: the risk of respondents giving an incorrect interpretation of the change (information bias), by carefully describing the defence project through Figure 5; and methodological misspecification bias, by specifically training interviewers in order to prevent respondents unfamiliar with the valuation questions actually answering different questions. In addition, in order to avoid biases related to the questionnaire structure and wording, a pilot survey (30 interviews in Venice) was carried out. Some modifications were done to the questionnaire for the main survey.

\section{Sampling design}

The random sample of tourists and day-visitors to Venice was stratified according to the six areas of Venice where visitors mainly transit (Zattere, Piazzale Roma, Tronchetto, Santa Lucia, Punta Sabbioni and San Marco), 
visitors' place of origin (nationals and foreigners, from the information provided by the Tourist Office of Venice) and times of the survey, with a higher number of interviews at the weekends.

\section{Donation models for nationals and for foreigners}

Individual donations depend on numerous variables. In particular, visitors may donate because (1) they care about the good under valuation, or (2) they gain enjoyment from their donation per se (Steinberg, 1987; Andreoni, 1989). With regards to point (1), motives (a)-(e), highlighted in the section of the questionnaire, may justify that care; while point (2) stresses the fact that people may donate since they feel satisfaction from the mere voluntary donation act (warm glow).

We model visitors' behaviour as follows. First of all, let us indicate the individual utility function of visitors to Venice $U_{i}=U_{i}\left(w_{\mathrm{i}}, x_{i}, Q, D_{i}\right){ }^{6} i=1, \ldots, n$, where $w_{i}$ is an $n$-dimensional vector of the individual characteristics, $x_{i}$ is the value of private goods consumed, $Q$ is the total supply of Venice quality and $D_{i}$ is the donation. When a warm glow is not present $U_{i}=U_{i}\left(w_{i}, x_{i}, Q\right)$.

Let us assume that $Q$ is both publicly and privately financed. Therefore $Q$ $=G+T$, where $G$ is visitors' total donations and $T$ represents the total public funds provided by the national government. Let us indicate $G=D_{i}+G_{-i}$, where $D_{i}$ is the donation of individual $i$, and $G_{-i}=\Sigma_{j \neq i} D_{j}$ represents the donations of everyone but $i$ (nationals and foreigners). Therefore, $Q=D_{i}+G_{-i}+T$, where $G_{-i}$ and $T$ are exogenously determined. Let us also assume that the national government funds the defence project with a share of income taxes instead of through a lump sum tax such as in Andreoni (1989).

Let us distinguish between national and foreign visitors. Nationals contribute to Venice's conservation through their income taxes and can also contribute through individual voluntary donations. Foreigners are of many nationalities and may have different characteristics and attitudes, but from the economic point of view they have in common the fact that they cannot contribute through their income taxes, since foreign governments do not fund the project, while they can contribute through individual voluntary donation. Therefore, with regards to the donation model for foreigners, we do not distinguish them according to nationality.

Finally, let us assume that each rational agent, perfectly informed, maximizes his or her utility.

\section{National visitors' donation model}

When visitor $i$ is a national

$$
\begin{gathered}
\max U_{N i}\left(w_{N i}, x_{N i}, Q, D_{N i}\right), \\
\text { s.t. } Y_{N i}=x_{N i}+D_{N i}+t_{N i} Y_{N i}, \\
Q=G_{-i}+D_{N i}+T, \\
T=\alpha t_{N i} Y_{N i}+T_{N-i} .
\end{gathered}
$$


Equation (2) is the individual budget constraint, $i=1, \ldots, m$, where $Y_{N i}$ is the income and $t_{N i}$ is the domestic income tax. Equation (4) represents the national public funds devoted to Venice's conservation, where $\alpha$ is the individual share (exogenously determined) of income tax $\left(t_{N i} Y_{N i}\right)$ devoted to the project by the government, $0<\alpha<1$, and $T_{N-i}$ is the share of income taxes of all Italian citizens but $i$ devoted to the project. Therefore, model (1)-(4) shows that a national visitor contributes to the public good provision directly through $D_{N i}$ and indirectly through $\alpha t_{N i} Y_{i}$.

By substituting Equation (2) in function (1) and Equation (4) in (3) and then in (1)

$$
\max U_{N i}\left(w_{N \mathrm{i}}, Y_{N i}\left(1-t_{N i}\right)-D_{N i}, G_{-i}+D_{N i}+\alpha t_{N i} Y_{i}+T_{N-i}, D_{N i}\right) .
$$

The donation demand for national visitors is

$$
D_{N i}^{*}=f_{N i}\left(w_{N i}, Y_{N i}\left(1-t_{N i}\right), G_{-i}+\alpha t_{N i} Y_{N i}+T_{N-i}\right) .
$$

\section{Foreign visitors' donation model}

When visitor $i$ is a foreigner, the maximization problem is

$$
\begin{gathered}
\max U_{F i}\left(w_{F i}, x_{F i}, Q, D_{F i}\right), \\
\text { s.t. } Y_{F i}=x_{F i}+D_{F i}+t_{F i} Y_{F i}, \\
Q=G_{-i}+D_{F i}+T .
\end{gathered}
$$

Equation (8) is a foreigner's budget constraint, $i=1, \ldots, s$, where $D_{F i}$ is the donation and $t_{F i}$ is the income tax. Model (7)-(9) shows that, since foreign governments do not fund the project, foreigners only contribute directly through their donations. Rewriting this problem as follows

$$
\max U_{i}\left(w_{F i}, Y_{F i}\left(1-t_{F i}\right)-D_{F i}, G_{-i}+D_{F i}+T, D_{F i}\right)
$$

the donation demand for foreigners is

$$
D_{F i}^{*}=f_{F i}\left(w_{F i}, Y_{F i}\left(1-t_{F i}\right), G_{-i}+T\right) \text {. }
$$

In order to estimate Equations (6) and (11) for the Venice conservation programme, data are provided by the CVM questionnaire.

\section{Data: descriptive statistics}

The random sample consisted of $24.2 \%$ Italians and $75.8 \%$ foreigners. More specifically, non-Italian Europeans accounted for $54.8 \%$ and non-Europeans $21 \%$. The non-Italian Europeans mainly came from Germany (12.7\%), the UK $(9.8 \%)$, France $(6.1 \%)$ and Austria $(4.3 \%)$, while the non-Europeans mainly 
come from the USA (9.5\%). Day-visitors are $44.3 \%$ of the whole sample, while the rest are tourists. ${ }^{7}$ Table 2 shows the percentages of day-visitors and tourists disaggregated according to their main nationalities, thus highlighting that the highest number of day-visitors and tourists are non-Italian Europeans.

Tourists stay on average 3.6 nights $(\mathrm{SD}=2.32)$. The majority $(61.2 \%)$ are accommodated in hotels, while $22.8 \%$ stay on campsites. In particular, Table 3 shows that non-Europeans mainly stay in hotels, that the highest percentage of those who stay on campsites are non-Italian Europeans, and the highest percentage of those who stay in flats are Italians.

The vast majority of respondents $(93.0 \%)$ are in favour of the Venice defence programme (95.0\% Italians, non-Italian Europeans $91.42 \%$ and non-Europeans $94.76 \%$ ), thus showing they prefer the quality change due to the implementation of the project.

With regards to respondents' attitudes towards cultural goods, $85 \%$ of respondents have visited other artistic towns in Italy (98.8\% Italians, $80 \%$ foreigners), while $93 \%$ (83.5\% Italians, 96\% foreigners) have done so abroad, thus showing a specific interest in artistic sites. More than $66.3 \%$ of respondents think that their country should spend more money on the conservation of cultural goods (MMCG) in general.

Regarding the first reason for conserving cultural goods (RCCG) (see Table 4), $47.5 \%$ of respondents (in particular non-Europeans) think that cultural goods should be conserved for the future of our children (bequest value), $21.9 \%$ because they exist and $6.7 \%$ for visitor satisfaction (in particular Italians). Europeans are more sensitive to the needs of society than non-Europeans; while a higher number of non-Europeans than Europeans believe that cultural goods

\begin{tabular}{|c|c|c|c|}
\hline Visitor category & Italians & Non-Italian Europeans & Non- Europeans \\
\hline Day-visitors & 38.83 & 46.95 & 14.22 \\
\hline Tourists & 12.57 & 61.04 & 26.39 \\
\hline Whole sample & 24.20 & 54.80 & 21.00 \\
\hline
\end{tabular}

Table 3. Tourists distinguished according to accommodation and nationality (CVM data 2002).

\begin{tabular}{lcccc}
\hline Accommodation & Whole sample & Italian & Non-Italian European & Non-European \\
& & & & \\
Hotel & 61.22 & 58.57 & 56.76 & 72.79 \\
Campsite & 22.80 & 20.00 & 26.18 & 16.33 \\
Flat & 5.21 & 8.57 & 5.88 & 2.04 \\
Hostel & 4.67 & 2.86 & 5.00 & 4.76 \\
Friends/relatives & 2.33 & 7.14 & 1.77 & 1.36 \\
Other accommodation & 3.77 & 2.86 & 4.41 & 2.72 \\
\hline
\end{tabular}


Table 4. Reasons justifying cultural site conservation in general (\% of respondents, 2002).

Reasons

Visitor satisfaction

Needs of the society

Bequest value

To make the world better

Existence value

Good cause

To boost tourism

Culture is a world resource

Whole sample Italians Non-Italian Europeans Non-Europeans

$\begin{array}{rrrr}6.7 & 8.3 & 6.6 & 5.2 \\ 13.1 & 14.1 & 14.0 & 9.5 \\ 47.5 & 39.3 & 47.4 & 57.1 \\ 5.1 & 4.1 & 5.3 & 5.7 \\ 21.9 & 23.5 & 22.1 & 19.5 \\ 3.9 & 7.9 & 3.3 & 1.0 \\ 0.8 & 1.6 & 0.4 & 1.0 \\ 1.0 & 1.2 & 0.9 & 1.0\end{array}$

make the world better. Members of cultural heritage conservation organizations are $9.8 \%$ of respondents, in particular $11.13 \%$ of non-Italian Europeans, $11.43 \%$ of non-Europeans and $5.37 \%$ of Italians. Their mean voluntary expense for cultural heritage in general is €208.51 per year and it is higher for Italians (€221.89) than for foreigners (€204.75).

The main recreational activity in Venice (RAV) is sightseeing on foot for the majority of respondents (in Figure 4 also distinguished according to a certain number of single nationalities), mainly for the sub-sample of non-Europeans and in particular for USA and British respondents. The second activity is visiting cultural goods, such as museums and churches, mainly for the subsample of nonItalian Europeans and in particular for Germans; while the third is travelling by gondola or motor boat, mainly for non-Italian Europeans and in particular for the French.

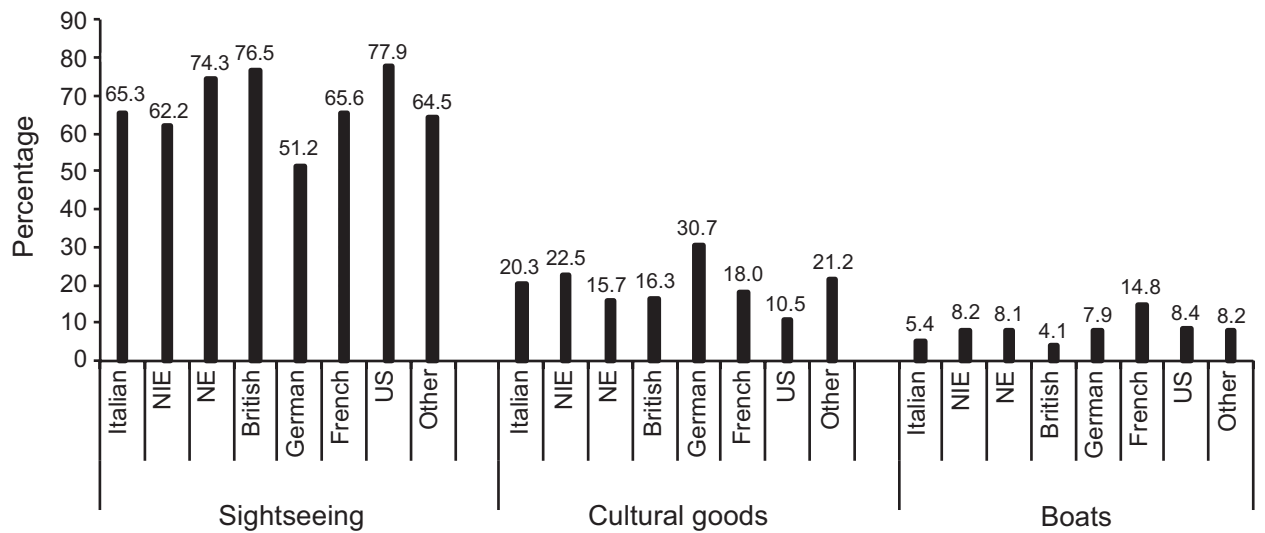

Figure 4. Recreational activities in Venice by nationality (percentage of respondents, 2002).

Note: NIE - non-Italian Europeans; NE - non-Europeans. 
Table 5. Income categories according to nationality (\% of respondents, 2002).

\begin{tabular}{lcccc}
\hline Income category & $\begin{array}{c}\text { Whole sample } \\
(\%)\end{array}$ & $\begin{array}{c}\text { Italian } \\
(\%)\end{array}$ & $\begin{array}{c}\text { Non-Italian European } \\
(\%)\end{array}$ & $\begin{array}{c}\text { Non-European } \\
(\%)\end{array}$ \\
$€ 1-10,000$ & 1.2 & 2.48 & 1.10 & - \\
$€ 11,000-15,000$ & 3.2 & 4.96 & 2.37 & 3.34 \\
$€ 16,000-20,000$ & 8.0 & 14.88 & 6.75 & 3.33 \\
$€ 21,000-25,000$ & 8.7 & 9.09 & 8.58 & 8.57 \\
$€ 26,000-30,000$ & 8.6 & 7.43 & 10.04 & 6.19 \\
$€ 31,000-35,000$ & 6.8 & 6.61 & 6.75 & 7.14 \\
$€ 36,000-40,000$ & 4.7 & 2.89 & 5.66 & 4.29 \\
$€ 41,000-45,000$ & 6.6 & 3.72 & 6.02 & 11.43 \\
$€ 46,000-50,000$ & 4.2 & 0.83 & 5.11 & 5.71 \\
$€ 51,000+$ & 6.4 & 0.83 & 5.47 & 15.24 \\
Missing income & 41.6 & 46.28 & 42.15 & 34.76 \\
\hline
\end{tabular}

With regards to the income category, $58.4 \%$ of respondents specify their annual household net income category. Table 5 shows that among those who state their income according to the categories considered here, the highest percentage of those who state a low income are Italians, those who state a medium income are non-Italian Europeans, and those who state a high income are nonEuropeans; while $46.28 \%$ of Italians, $42.15 \%$ of non-Italian Europeans and $34.76 \%$ of non-Europeans do not state their incomes, thus suggesting that nonEuropeans have a greater propensity to state their income than Europeans.

\section{Outliers and protest answers}

Respondents state values from $€ 0$ to $€ 100$. Questions (1)-(3) permit different kinds of respondents to be distinguished. As shown in Figure 5, 28.9\% of respondents are unwilling to donate; $71.1 \%$ would be willing to donate at least $€ 1$ as a contribution to the cost of the defence project (more specifically, $77.7 \%$ of Italians and $69.0 \%$ of foreigners). Those who are willing to donate are distinguished into those who would be willing to donate only $€ 1(30.4 \%)$ and those who state they would be willing to donate more than $€ 1(40.7 \%)$. Nevertheless, only $27.4 \%$ of respondents actually specify a value higher than $€ 1$, while $13.3 \%$ of respondents willing to donate more than $€ 1$ are unable to specify a higher value.

The highest values were not truncated or excluded from the sample, since a donation of at most $€ 100$ per year seems to us reasonable for Venice's conservation. Table 6 presents the WTD distribution for the whole sample and the main nationality groups. In particular, zero values represent those who are unwilling to donate, while the number of those stating $€ 1$ is the sum of those who are willing to donate $€ 1$ as their maximum donation and of those who are willing to donate more than $€ 1$ but do not specify their maximum donation. We highlight that the highest percentage of those unwilling to donate is among non-Italian Europeans and that of those who state the lowest WTD $(€ 1)$ and the highest WTD (from €21-25 to €51-100) is among Italians. 


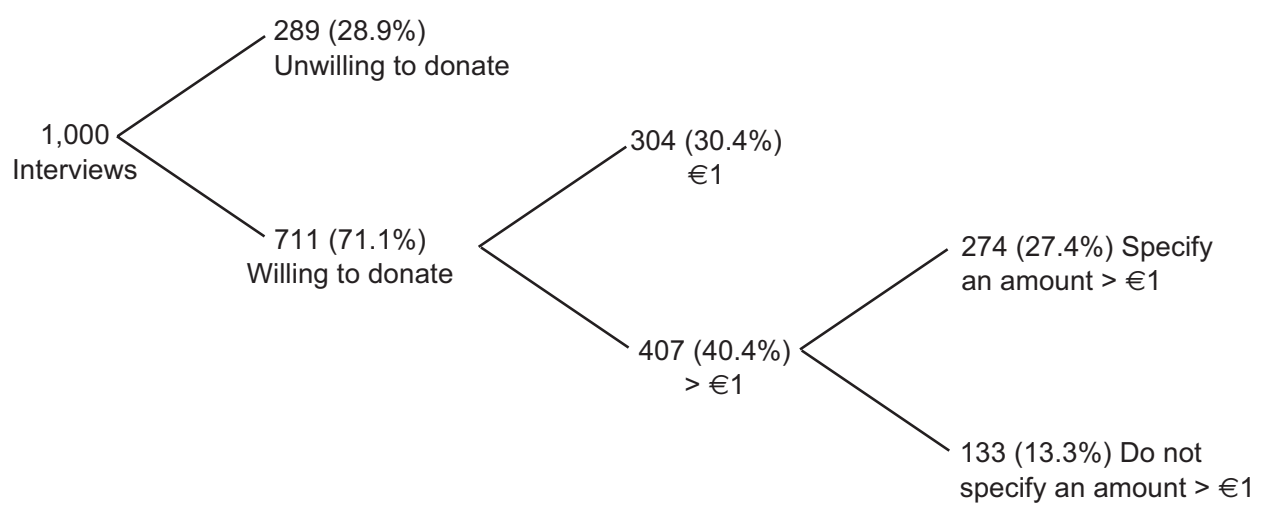

Figure 5. Respondents willing and unwilling to donate.

Table 6. Willingness to donate (WTD) distribution (\% of respondents, 2002).

\begin{tabular}{lcccc}
\hline WTD $(€)$ & Whole sample & Italians & Non-Italian Europeans & Non-Europeans \\
& $(1)$ & $(2)$ & $(3)$ & $(4)$ \\
& & & & \\
Zero & 28.9 & 22.3 & 34.3 & 22.4 \\
1 & 43.7 & 45.5 & 42.5 & 44.8 \\
$2-5$ & 10.3 & 11.6 & 9.5 & 10.9 \\
$6-10$ & 9.5 & 10.3 & 7.8 & 12.9 \\
$11-15$ & 1.5 & 2.5 & 1.3 & 0.9 \\
$16-20$ & 2.1 & 1.2 & 1.8 & 3.8 \\
$21-25$ & 1.1 & 2.5 & 0.0 & 2.4 \\
$26-50$ & 2.4 & 3.3 & 2.4 & 1.4 \\
$51-100$ & 0.5 & 0.8 & 0.4 & 0.5 \\
\hline
\end{tabular}

In order to identify outliers (observations that take implausibly low or high values with reference to the rest of the data), an ordinary least squares (OLS) regression is estimated by considering household income as an independent variable. Through regression diagnostics (Studentized Residual, DFFITS [difference in fits], Cook's Distance and DFBETAS [difference in betavalues]) a certain number of observations (from 16 to 25) are detected as outliers. Among them, no zero value is identified as an outlier. Nevertheless, this regression has quite a low adjusted $R^{2}$ of 0.0106 . In addition, $41.6 \%$ of respondents do not state their income and cannot be tested through regression diagnostics. Since this suggests that we have to be cautious in deleting these observations, no observation is deleted as an outlier.

With regards to the identification of protest answers, respondents unwilling to donate are asked their non-donation motives. Table 7 shows non-donation motives according to nationality. The main non-donation motive is believing that paying for the programme is a state's duty (37.7\%), mainly for Europeans and in particular for Germans and the French. Another non-donation motive is the fact that visitors do not live in Venice (18.3\%), mainly for non-Italian 
Table 7. Non-donation motives by nationality (\% of respondents, 2002).

\begin{tabular}{lcrrrrrrr}
\hline Non-donation motives & $\begin{array}{c}\text { Whole } \\
\text { sub- } \\
\text { sample }\end{array}$ & NIE $^{\mathrm{a}}$ & NE $^{\mathrm{b}}$ & IT & GB & D & FR & USA \\
State's duty & 37.7 & 39.9 & 29.8 & 37.0 & 21.4 & 53.1 & 45.4 & 26.1 \\
I do not live in Venice & 18.3 & 22.3 & 12.8 & 9.3 & 28.6 & 17.2 & 18.2 & 13.1 \\
Other projects are better & 11.8 & 8.0 & 29.8 & 9.3 & 17.8 & 3.1 & 9.1 & 30.4 \\
Non-profit agencies waste money & 11.4 & 8.0 & 17.0 & 18.5 & 14.3 & 3.1 & 13.6 & 21.7 \\
Enough taxes & 7.6 & 8.5 & 2.0 & 9.3 & 14.3 & 4.7 & 9.1 & 0.0 \\
More information about the project & 5.5 & 4.3 & 4.3 & 11.1 & 0.0 & 7.8 & 0.0 & 8.7 \\
Nature is damaged & 4.2 & 4.8 & 4.3 & 1.9 & 3.6 & 4.7 & 4.6 & 0.0 \\
Other motives & 3.5 & 4.2 & 0.0 & 3.6 & 0.0 & 6.3 & 0.0 & 0.0 \\
\hline
\end{tabular}

${ }^{\mathrm{a}} \mathrm{NIE}=$ Non-Italian Europeans $;{ }^{\mathrm{b}} \mathrm{NE}=$ Non-Europeans.

Europeans and in particular for the British. Of these respondents, $11.8 \%$ prefer other projects (mainly non-Europeans and in particular US respondents), $11.4 \%$ do not donate because they believe that non-profit agencies waste money (mainly Italians and US respondents), 7.6\% say they pay enough taxes (mainly the British), while $5.5 \%$ need more information about the project (mainly Italians). Finally $4.2 \%$, mainly non-Italian Europeans, think that nature will be damaged if the conservation programme is implemented.

Among these non-donation motives, paying for Venice is a 'state's duty', 'I do not live in Venice', 'non-profit agencies waste money', and I pay 'enough taxes' may be protest answers. These observations can be included in the computation of the mean WTD as zero values, or removed (Haab and McConnell, 2002). Since the mean WTD computed by including these zero values is lower than that obtained by excluding them, in order to be conservative we compute the WTD by also considering these observations.

\section{Donation motives}

Respondents in the subsample of those willing to donate are asked their donation motives (DM) (first choice and second choice). With regards to the first choice motive of donation, Table 8 shows that the majority $(53.7 \%)$ of these respondents state the bequest value. This is the main donation motive for all the nationalities considered here, in particular for the British $(62.9 \%)$ and Germans (60.3\%), thus showing a widespread sense of responsibility about future generations. The option value is stated by $17.4 \%$ of respondents; the highest percentages of who would pay for having the option of visiting Venice in the future are among non-Europeans, in particular US respondents. An altruistic motive regarding the present generation is stated by $12.2 \%$ of respondents, in particular $18 \%$ of French and $18.1 \%$ of US respondents; while $10.6 \%$ state they would donate just to know that Venice exists, in particular $23.1 \%$ of the French. Good cause is stated by $4.1 \%$ of respondents, in particular by Germans and Italians. Finally, other motives, stated by $1 \%$ of respondents, are: Venice is beautiful; Venice represents culture; Venice is artistic; if everyone donates, Venice will be saved; and pleasure. As a second choice, the main 
Table 8. Donation motives (first choice) by nationality (\% of respondents, 2002).

\begin{tabular}{lcrrrrrrr}
\hline Donation motives & $\begin{array}{c}\text { Whole } \\
\text { sub- } \\
\text { sample }\end{array}$ & NIE $^{\mathrm{a}}$ & NE $^{\mathrm{b}}$ & IT & GB & D & FR & USA \\
Bequest value & 53.7 & 51.9 & 55.2 & 55.9 & 62.9 & 60.3 & 41.0 & 54.2 \\
Option value & 17.4 & 18.6 & 22.7 & 10.6 & 14.3 & 14.3 & 15.4 & 18.1 \\
Altruism & 12.2 & 11.1 & 11.0 & 15.4 & 14.3 & 1.6 & 18.0 & 18.1 \\
Existence value & 10.6 & 12.8 & 5.5 & 10.6 & 7.1 & 11.1 & 23.1 & 5.7 \\
Good cause & 4.1 & 3.9 & 2.5 & 5.9 & 1.4 & 7.9 & 2.6 & 1.4 \\
Other motives & 1.0 & 1.1 & 1.8 & 0.0 & 0.0 & 4.8 & 0.0 & 1.4 \\
No answer & 1.0 & 0.6 & 1.2 & 1.6 & 0.0 & 0.0 & 0.0 & 1.5 \\
\hline
\end{tabular}

${ }^{\mathrm{a}} \mathrm{NIE}=$ Non-Italian Europeans; ${ }^{\mathrm{b}} \mathrm{NE}=$ Non-Europeans.

motives of donations are: good cause (22\%); option value (18.8\%); altruism $(16.7 \%)$; bequest value $(15.4 \%)$; and existence value $(11.9 \%)$. Other motives $(0.7 \%)$ are: Venice is beautiful and Venice represents culture. Of the respondents, $13.5 \%$ state they do not have a second choice motive; while $1 \%$ do not answer.

These results highlight that warm glow does not belong to the preferences of these visitors to Venice. In fact, to the question about donation motives one Italian respondent chose the item 'other motive' (see the section of the questionnaire) and specified 'pleasure' as their first choice motive, but it is not clear whether this should be interpreted as warm glow or satisfaction from Venice's conservation.

\section{Observed mean WTDs}

The observed mean WTDs per year are presented in Table 9 according to nationalities and in Table 10 according to donation motives and recreational activities to Venice. In Table 9 the mean WTDs are computed according to the different ways of considering those who are uncertain to donate. Column (1) shows that the mean WTD, computed by considering all respondents as if they would be certain to donate, is $€ 4.34$ (median $€ 1$, standard deviation $€ 10.47$ ). With regards to nationalities, column (1) also shows that on average non-Europeans (€4.63) would be willing to donate more than non-Italian Europeans (€3.60); in particular, French and Germans give the smallest mean WTDs (€1.74 and $€ 2.07$, respectively), while US respondents and Italians the highest (€5.93 and $€ 5.76$, respectively).

With regards to the degree of certainty to donate, $64.4 \%$ of respondents willing to donate are $100 \%$ sure that they would donate the amount stated if actually asked, $20.1 \%$ state a degree of certainty from $70 \%$ to $90 \%, 11.3 \%$ from $40 \%$ to $60 \%, 2.8 \%$ from $10 \%$ to $40 \%$, while $1.4 \%$ do not state their degree of certainty to donate and are considered as zero values. Column (2) shows that the mean degree of certainty to donate is 0.88 (whole sample), while column (3) shows the weighted mean WTD computed by multiplying the values in column (1) by the mean degree of certainty to donate in column (2). 
Table 9. Observed mean WTDs (Euro 2002) and degrees of certainty to donate according to nationality.

\begin{tabular}{|c|c|c|c|c|c|}
\hline & $\begin{array}{c}\text { Mean } \\
\text { WTD } \\
(1)\end{array}$ & $\begin{array}{c}\text { Mean } \\
\text { degree of } \\
\text { certainty to } \\
\text { donate } \\
\text { (2) }\end{array}$ & $\begin{array}{c}\text { Weighted } \\
\text { mean } \\
\text { WTD } \\
(3)\end{array}$ & $\begin{array}{c}\text { Mean } \\
\text { WTD: } \\
\text { WTD=0 for } \\
\text { uncertain to } \\
\text { donate } \\
\text { (4) }\end{array}$ & $\begin{array}{l}\text { Mean } \\
\text { WTD: } \\
\text { certain to } \\
\text { donate } \\
\text { only } \\
(5)\end{array}$ \\
\hline Whole sample & $\begin{array}{c}4.34 \\
(5.22)^{\mathrm{a}}\end{array}$ & 0.88 & $\begin{array}{c}3.82 \\
(4.59)\end{array}$ & $\begin{array}{c}2.93 \\
(3.52)\end{array}$ & $\begin{array}{c}6.40 \\
(7.69)\end{array}$ \\
\hline Non-Italian European & $\begin{array}{c}3.60 \\
(4.41)\end{array}$ & 0.87 & $\begin{array}{c}3.13 \\
(3.84)\end{array}$ & $\begin{array}{c}2.30 \\
(2.82)\end{array}$ & $\begin{array}{l}5.88 \\
(7.2)\end{array}$ \\
\hline Non-European ${ }^{\mathrm{b}}$ & 4.63 & 0.90 & 4.12 & 3.60 & 6.64 \\
\hline Italian & $\begin{array}{c}5.76 \\
(6.78)\end{array}$ & 0.89 & $\begin{array}{c}5.13 \\
(6.03)\end{array}$ & $\begin{array}{c}3.78 \\
(4.45)\end{array}$ & $\begin{array}{c}7.04 \\
(8.28)\end{array}$ \\
\hline British & $\begin{array}{c}3.88 \\
(4.66)\end{array}$ & 0.95 & $\begin{array}{c}3.69 \\
(4.42)\end{array}$ & $\begin{array}{c}3.69 \\
(4.43)\end{array}$ & $\begin{array}{c}6.46 \\
(7.75)\end{array}$ \\
\hline US & $\begin{array}{c}5.93 \\
(7.19)\end{array}$ & 0.92 & $\begin{array}{c}5.51 \\
(6.61)\end{array}$ & $\begin{array}{c}4.49 \\
(5.44)\end{array}$ & $\begin{array}{c}7.91 \\
(9.59)\end{array}$ \\
\hline German & $\begin{array}{c}2.07 \\
(2.34)\end{array}$ & 0.80 & $\begin{array}{c}1.66 \\
(1.87)\end{array}$ & $\begin{array}{c}1.37 \\
(1.55)\end{array}$ & $\begin{array}{c}6.21 \\
(7.01)\end{array}$ \\
\hline French & $\begin{array}{c}1.74 \\
(1.99)\end{array}$ & 0.89 & $\begin{array}{c}1.55 \\
(1.77)\end{array}$ & $\begin{array}{c}1.26 \\
(1.44)\end{array}$ & $\begin{array}{c}3.08 \\
(3.52)\end{array}$ \\
\hline
\end{tabular}

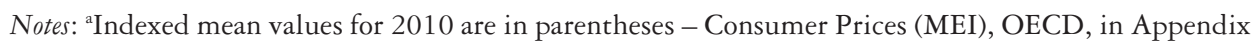
A. ' Indexed values are not presented for non-Italian Europeans.

Table 10. Observed mean WTDs $(€)$ and degrees of certainty to donate according to main donation motives and recreational activities to Venice (2002).

\begin{tabular}{|c|c|c|c|c|c|}
\hline Donation motive & $\begin{array}{c}\text { Mean } \\
\text { WTD } \\
(1)\end{array}$ & $\begin{array}{c}\text { Mean } \\
\text { degree of } \\
\text { certainty to } \\
\text { donate } \\
\text { (2) }\end{array}$ & $\begin{array}{c}\text { Weighted } \\
\text { mean } \\
\text { WTD } \\
(3)\end{array}$ & $\begin{array}{c}\text { Mean } \\
\text { WTD: } \\
\text { WTD=0 for } \\
\text { uncertain to } \\
\text { donate } \\
\text { (4) }\end{array}$ & $\begin{array}{l}\text { Mean } \\
\text { WTD: } \\
\text { certain to } \\
\text { donate } \\
\text { only } \\
(5)\end{array}$ \\
\hline Bequest value & 6.68 & 0.90 & 6.01 & 4.43 & 6.58 \\
\hline Option value & 4.52 & 0.88 & 3.98 & 3.21 & 5.04 \\
\hline Altruism & 6.37 & 0.88 & 5.61 & 4.55 & 7.20 \\
\hline Existence value & 4.45 & 0.86 & 3.83 & 3.36 & 5.86 \\
\hline \multicolumn{6}{|c|}{ Recreational activity in Venice } \\
\hline Sight-seeing & 3.67 & 0.90 & 3.30 & 2.59 & 5.04 \\
\hline Cultural goods & 6.13 & 0.86 & 5.27 & 3.84 & 10.79 \\
\hline Boat & 3.81 & 0.72 & 2.74 & 1.45 & 6.41 \\
\hline
\end{tabular}


On average, non-Europeans are more willing to donate and more certain to donate than non-Italian Europeans. In particular, considering single nationalities, British respondents are on average less willing to donate than Italians and US respondents but their mean degree of certainty to donate is higher than that of Italians and US respondents.

Column (4) presents the mean WTD computed by considering those who are uncertain to donate (defined here as those who state a degree of certainty to donate $<100$ and those who do not state their degree of certainty to donate) as unwilling to donate (WTD $=0$ ), while column (5) shows the mean WTD by considering only those who are certain to donate. We highlight that in column (5) mean WTDs are considerably higher than mean WTDs computed without excluding those who are uncertain to donate; column (4) provides the most conservative mean values.

Furthermore, in Table 9, in order to update the values of columns (1), (3), (4) and (5), we present indexed values for 2010 in brackets $(2002=100)$. Appendix A shows the different Organisation for Economic Co-operation and Development (OECD) indexes used: OECD-Total for the whole sample, OECDEurope for non-Italian Europeans and OECD indexes for the single nationalities considered here. We highlight that we did not find an index suitable for nonEuropeans; therefore we did not index the corresponding mean WTDs. According to these indexes comparing 2010 values with 2002 values, we see that the former are $20 \%$ higher than the latter for the whole sample, $22 \%$ higher for non-Europeans and from $13 \%$ to $21 \%$ higher for the single nationalities. Nevertheless, the values thus obtained have to be considered with caution. In particular, indexes OECD-Total and OECD-Europe are not completely suitable for the whole sample and non-Italian Europeans, respectively, since the former excludes non-OECD countries, while the latter also considers Italy, the index of which is lower than the OECD-Europe index.

Finally, Table 10 shows that regarding donation motives, those who state bequest value as their donation motive have the highest mean WTD (column 1 ), the highest degree of certainty to donate (column 2) and the highest weighted mean WTD (column 3); while those who state 'altruism' as donation motive have the highest mean WTD computed by considering those who are uncertain to donate as WTD $=0$ (column 4) and also that computed by considering those who are certain to donate only (column 5). With regards to recreational activities in Venice, instead, those who state they visit Venice for cultural goods have much higher mean WTDs than those stated for other activities, while the highest mean degree of certainty to donate is stated by those who are sightseeing on foot in Venice.

\section{The statistical model}

The theoretical validity of CVM results is measured by regressing the WTD on a group of independent variables (determinants). Since visitors to Venice do not state negative WTD and a certain number of zero values are present, we can distinguish two decision stages: (1) the decision to donate or not (selection stage); and (2) the decision on how much to donate (outcome stage). We model 
these two decisions separately through a two-stage model, ${ }^{8}$ which admits that different sets of variables may determine the decision to donate and the maximum WTD. The two-stage estimator proposed by Heien and Wessells (1990) is applied, according to which all observations are used for both stages.

The first stage is estimated through a Probit model. WTD ${ }_{1 i}^{*}$ is a latent variable which represents the willingness to donate of respondent $i$. Let us write the following function

$$
W T D_{1 i}^{*}=a_{1}^{\prime} x_{1 i}+\mu_{1 i}
$$

where $i=1, \ldots, r, r$ is the sample size, $x_{1 i}$ is a vector of independent variables referred to respondent $i, a_{1}$ is a vector of coefficients to be estimated and $\mu_{1 i}$ is a random component normally distributed, $\mu_{1 i} \sim N\left(0, \sigma_{1}^{2}\right) . W T D_{1 i}{ }^{*}$ is unobservable, therefore we define the following dummy variable $I_{i}$ (Amemyia, 1978; Maddala, 1983)

$$
I_{i}=1 \text { if } W T D_{1 i}^{*}>0 ; I_{i}=0 \text { otherwise. }
$$

From Equation (12), relation (13) and the assumptions made on the stochastic term, the probability that a respondent (drawn randomly) is willing to donate is

$$
P\left(I_{i}=1\right)=P\left(a_{1}^{\prime} x_{1 i}+\mu_{1 i}>0\right)=\Phi\left[a_{1}^{\prime} x_{1 i} / \sigma_{1}\right]
$$

where $\Phi(\cdot)$ is the standard normal distribution. According to the Maximum Likelihood estimator, the log-likelihood function is

$$
L=\sum_{i=1}^{N} I_{i} \ln \left\{\Phi\left[a_{1}^{\prime} x_{1 i} / \sigma_{1}\right]\right\}+\sum_{i=1}^{N}\left(1-I_{i}\right) \ln \left\{1-\Phi\left[a_{1}^{\prime} x_{1 i} / \sigma_{1}\right]\right\}
$$

For each respondent the inverse Mill's Ratio $(M R)$ is computed as follows (Heien and Wessels, 1990)

$$
M R_{i}= \begin{cases}\phi\left(z_{i}\right) / \Phi\left(z_{i}\right) & \text { if } I_{i}=1 \\ \phi\left(z_{i}\right) /\left[1-\Phi\left(z_{i}\right)\right] & \text { otherwise }\end{cases}
$$

where $z_{i}=\boldsymbol{a}^{\prime} x_{1 i} / \sigma_{1}$ and $\phi(\cdot)$ is the standard normal density. $M R$ is used as an independent variable in the second-stage OLS regression

$$
W T D_{2 i}=a_{2}^{\prime} x_{2 i}+b M R_{i}+\mu_{2 i}
$$

where $W T D_{2 i}$ is the observed WTD, $x_{2 i}$ is a vector of independent variables, $a_{2}$ (vector) and $b$ are coefficients and $\mu_{2 i}$ is a random component with a mean of zero. The coefficient $b$ is the estimate of the ratio $\sigma_{12} / \sigma_{1}$, where $\sigma_{12}$ is the covariance between the stochastic terms of the equations about the two stages and $\sigma_{1}$ is the standard error of the stochastic term of the first stage (Heckman, 1976). If $b=0$, the two stages are independent. 


\section{Results of regression models according to nationality}

We present the results of four robust two-stage models (White, 1980): model I for the whole sample (Table 11), model II for Italians (Table 11), model III for non-Italian Europeans (Table 12) and model IV for non-Europeans (Table 12). All the WTD values, from $€ 0$ to $€ 100$, are considered. WTD $=0$ is ascribed to those who are uncertain to donate (see the section on observed mean WTDs) ${ }^{9}$; while WTD $=1$ is ascribed to those who answered yes to questions (1) and (2), that is, they are willing to donate $€ 1$ and more than $€ 1$, respectively, but did not specify their maximum WTD in question (3). Observations with missing WTDs are excluded.

The main independent variables of interest are highlighted in italics in the section on descriptive statistics, while the complete list is presented in Appendix B. ${ }^{10}$ In particular, regarding household net income the mean of each income category is considered for the sub-sample of those who specify it, while a zero value is considered for those (41.6\%) who do not specify their income category. In addition, the dummy missing income is created: 1 when respondents do not state income; 0 otherwise (Alberini, 1995; Alberini et al, 2005). The two-stage models are first estimated considering all the variables of interest, then stepwise estimations are made for $\alpha=0.05$ and presented here. The software STATA is used. We will see that, as expected, the significant independent variables are in part or totally different for each stage.

\section{Whole sample}

Regarding the whole sample (Table 11), being in favour of the Venice defence project and staying in hotels increase the probability of being willing to donate (PWTD) and the maximum WTD; while they decrease if the main recreational activity in Venice (RAV) is going by boat. The first stage (probit) also shows that PWTD decreases for non-Italian Europeans and if RAV is visiting cultural goods; while believing in more money for the conservation of cultural goods (MMCG) in general and that the reason for the conservation of cultural goods (RCCG) is bequest value or existence value, and staying on campsites increase it. The second stage (OLS), instead, shows that WTD increases if the $\mathrm{DM}$ is bequest value or altruism or existence value or option value; while it decreases if RAV is sightseeing on foot. The PWTD is lower for those who do not state their income (missing income); while, as expected, the maximum WTD increases the higher the income. Finally, the MR coefficient is nonsignificant, thus showing that for the whole sample the two decision stages are independent.

\section{Italians, non-Italian Europeans and non-Europeans}

Let us compare the main results for Italians, non-Italian Europeans and nonEuropeans, presented in Tables 11 and 12. With regards to household net income, Table 11 also shows that for those Italians who do not state income (missing income) PWTD is lower; for Italians who state income, the higher the income the lower PWTD. This result is unexpected, since it suggests that for Italians the probability that richer respondents are willing to donate is lower than that of the less rich. In addition, the maximum WTD of Italians is not 
Table 11. Probability of being willing to donate (PWTD) and willingness to donate (WTD) determinants: whole sample and Italians (2002).

\begin{tabular}{|c|c|c|c|c|}
\hline \multirow[t]{2}{*}{ Independent variables } & \multicolumn{2}{|c|}{ Whole sample: Model I a } & \multicolumn{2}{|c|}{ Italians: Model II ${ }^{\text {a }}$} \\
\hline & Probit ${ }^{b}$ & OLS $^{c}$ & Probit $^{d}$ & OLS $^{\mathrm{e}}$ \\
\hline In favour & $\begin{array}{l}2.022 \\
(4.29)\end{array}$ & $\begin{array}{l}1.478 \\
(3.15)\end{array}$ & & $\begin{array}{l}7.072 \\
(3.34)\end{array}$ \\
\hline Hotel & $\begin{array}{l}0.325 \\
(3.49)\end{array}$ & $\begin{array}{l}2.092 \\
(3.13)\end{array}$ & & \\
\hline RAV: boat & $\begin{array}{l}-0.588 \\
(-3.08)\end{array}$ & $\begin{array}{l}-2.308 \\
(-2.47)\end{array}$ & & $\begin{array}{l}-5.769 \\
(-2.23)\end{array}$ \\
\hline Non-Italian Europeans & $\begin{array}{l}-0.298 \\
(-3.42)\end{array}$ & & & \\
\hline RAV: cultural goods & $\begin{array}{l}-0.305 \\
(-2.84)\end{array}$ & & & \\
\hline RAV: sightseeing on foot & & $\begin{array}{l}-1.853 \\
(-2.07)\end{array}$ & & $\begin{array}{l}-5.186 \\
(-2.13)\end{array}$ \\
\hline MMCG & $\begin{array}{l}0.428 \\
(4.60)\end{array}$ & & & $\begin{array}{l}4.197 \\
(4.28)\end{array}$ \\
\hline RCCG: bequest value & $\begin{array}{l}0.278 \\
(2.83)\end{array}$ & & $\begin{array}{l}0.673 \\
(3.38)\end{array}$ & \\
\hline RCCG: existence value & $\begin{array}{l}0.311 \\
(2.54)\end{array}$ & & $\begin{array}{l}0.443 \\
(1.99)\end{array}$ & \\
\hline Campsite & $\begin{array}{l}0.458 \\
(3.34)\end{array}$ & & & \\
\hline DM: bequest value & & $\begin{array}{l}3.523 \\
(5.90)\end{array}$ & & \\
\hline DM: altruism & & $\begin{array}{l}3.891 \\
(2.99)\end{array}$ & & \\
\hline DM: existence value & & $\begin{array}{l}2.609 \\
(2.90)\end{array}$ & & \\
\hline DM: option value & & $\begin{array}{l}2.536 \\
(4.22)\end{array}$ & & \\
\hline RVV: cultural events & & & $\begin{array}{l}0.544 \\
(2.00)\end{array}$ & \\
\hline Higher education & & & $\begin{array}{l}-0.415 \\
(-2.39)\end{array}$ & \\
\hline Age 41-50 & & & $\begin{array}{l}0.475 \\
(2.34)\end{array}$ & \\
\hline Missing income & $\begin{array}{l}-0.264 \\
(-3.03)\end{array}$ & & $\begin{array}{l}-0.739 \\
(-2.08)\end{array}$ & \\
\hline Income & & $\begin{array}{l}0.018 \\
(2.04)\end{array}$ & $\begin{array}{l}-0.014 \\
(-2.22)\end{array}$ & \\
\hline Constant & $\begin{array}{l}-2.337 \\
(-4.70)\end{array}$ & $\begin{array}{l}-0.637 \\
(-1.12)\end{array}$ & $\begin{array}{l}0.470 \\
(1.23)\end{array}$ & $\begin{array}{l}-2.901 \\
(-2.81)\end{array}$ \\
\hline
\end{tabular}

Notes: ${ }^{\mathrm{a}} z$ statistics for probit in brackets, $t$ statistics for ordinary least squares (OLS). ${ }^{b}$ Number of obs $=$ 984; Wald $\mathrm{chi}^{2}(10)=98.07$; Prob $>\mathrm{chi}^{2}=0$; Log pseudo-likelihood $=-594.84638$, McKelveyZavoina $R^{2}=0.300 .{ }^{\mathrm{C}} \mathrm{Number}$ of obs $=984 ; \mathrm{F}(9,974)=10.89 ;$ Prob $>\mathrm{F}=0$; Adj $R^{2}=0.061 .{ }^{\mathrm{d}}$ Number of obs $=238$; Wald $\mathrm{chi}^{2}(7)=25.89$; Prob $>\mathrm{chi}^{2}=0.0005$; Log pseudo-likelihood $=-148.6605$; McKelvey-Zavoina $R^{2}=0.185$. ${ }^{\mathrm{e}}$ Number of obs $=238 ; \mathrm{F}(4,233)=6.19 ;$ Prob $>\mathrm{F}=0 ; \operatorname{Adj} R^{2}=0.049$. 
Table 12. Probability of being willing to donate (PWTD)/willingness to donate (WTD) determinants: non-Italian Europeans and non-Europeans (2002).

\begin{tabular}{|c|c|c|c|c|}
\hline \multirow[t]{2}{*}{ Independent variables } & \multicolumn{2}{|c|}{$\begin{array}{c}\text { Non-Italian Europeans: } \\
\text { Model III }^{\text {a }}\end{array}$} & \multicolumn{2}{|c|}{$\begin{array}{c}\text { Non-Europeans: } \\
\text { Model IV }\end{array}$} \\
\hline & Probit $^{\mathrm{b}}$ & OLS $^{c}$ & Probit $^{\mathrm{d}}$ & OLS $^{\mathrm{e}}$ \\
\hline In favour & $\begin{array}{l}1.667 \\
(3.29)\end{array}$ & & & \\
\hline Hotel & $\begin{array}{l}0.374 \\
(2.92)\end{array}$ & & $\begin{array}{l}0.545 \\
(2.86)\end{array}$ & $\begin{array}{l}3.682 \\
(4.11)^{\mathrm{a}}\end{array}$ \\
\hline RVV: work/study & $\begin{array}{l}0.595 \\
(1.97)\end{array}$ & $\begin{array}{l}-1.655 \\
(-3.73)\end{array}$ & & \\
\hline RAV: cultural goods & & & $\begin{array}{l}0.887 \\
(2.22)\end{array}$ & \\
\hline RAV: sightseeing on foot & $\begin{array}{l}0.405 \\
(3.29)\end{array}$ & & $\begin{array}{l}0.878 \\
(2.65)\end{array}$ & \\
\hline MMCG & $\begin{array}{l}0.353 \\
(2.91)\end{array}$ & & $\begin{array}{l}0.743 \\
(3.57)\end{array}$ & \\
\hline MMN & & & $\begin{array}{l}-0.503 \\
(-2.23)\end{array}$ & \\
\hline RCCG: option value & & & $\begin{array}{l}-0.558 \\
(-2.00)\end{array}$ & \\
\hline Campsite & $\begin{array}{l}0.603 \\
(3.55)\end{array}$ & & & \\
\hline Improving public transport & $\begin{array}{l}0.272 \\
(2.28)\end{array}$ & & & \\
\hline DM: bequest value & & $\begin{array}{l}1.472 \\
(2.05)\end{array}$ & & \\
\hline Missing income & & & $\begin{array}{l}-0.695 \\
(-3.45)\end{array}$ & \\
\hline Income & & $\begin{array}{l}0.026 \\
(2.60)\end{array}$ & & $\begin{array}{l}0.035 \\
(2.38)\end{array}$ \\
\hline MR & & $\begin{array}{l}5.523 \\
(3.94)\end{array}$ & & \\
\hline Constant & $\begin{array}{l}-2.742 \\
(-4.89)\end{array}$ & $\begin{array}{l}-2.776 \\
(-3.04)\end{array}$ & $\begin{array}{l}-0.772 \\
(-2.11)\end{array}$ & $\begin{array}{l}0.063 \\
(0.09)\end{array}$ \\
\hline
\end{tabular}

Notes: ${ }^{a} z$ statistics for probit in brackets, $t$ statistics for OLS. ${ }^{b}$ Number of obs $=541$; Wald $\operatorname{chi}^{2}(7)=$ 45.99; Prob > chi $^{2}=0$; Log pseudo-likelihood $=-319.04262$; McKelvey-Zavoina $R^{2}=0.284$. ${ }^{c}$ Number of obs $=541 ; \mathrm{F}(4,536)=6.32$; Prob $>\mathrm{F}=0$; Adj $R^{2}=0.076 .{ }^{\mathrm{d}}$ Number of obs $=210$; Wald $\operatorname{chi}^{2}(7)=43.74 ;$ Prob $>$ chi $^{2}=0 ;$ Log pseudo-likelihood $=-119.33666 ;$ McKelvey-Zavoina $R^{2}=0.33$. ${ }^{e}$ Number of obs $=210 ; \mathrm{F}(2,207)=8.60 ;$ Prob $>\mathrm{F}=0.0003 ;$ Adjusted $R^{2}=0.092$.

affected by income. Table 12 shows, instead, that the higher the income the higher the maximum WTD for foreigners (non-Italian Europeans and nonEuropeans); while the PWTD is lower for non-Europeans who do not state income.

In addition, being in favour of the defence project increases the WTD for Italians and the PWTD for non-Italians Europeans. Sight-seeing on foot reduces the WTD for Italians, while it increases the PWTD for both categories of foreigners. Believing in MMCG increases the maximum WTD for Italians and the PWTD for foreigners. Believing that RCCG is bequest value or existence 
value increases the PWTD for Italians, while believing that the RCCG is the option value reduces it for non-Europeans. For Italians whose reason for visiting Venice (RVV) is cultural events the PWTD is higher, while for non-Italian Europeans whose RVV is work/study the PWTD is higher but the WTD is lower. Staying in a hotel increases the PWTD for both the foreigner categories and the WTD for non-Europeans only. In addition, having a higher education reduces the PWTD and being aged 41-50 increases it for Italians; believing in the need to spend more money to protect nature (MMN) reduces the PWTP for non-Europeans. Finally, the $M R$ coefficient is significant for non-Italian Europeans, thus showing that the two decision stages are dependent only for this visitor category.

\section{Venice visitors' PWTD and WTD functions}

Summarizing, as shown in Tables 11 and 12 the different categories of Venice visitors behave in different ways and have different PWTD and WTD functions, which we write as follows. The sign of each coefficient is highlighted at the bottom of each variable (in brackets). For Italians

$$
\begin{aligned}
& P W T D_{(\mathrm{I})}=f_{P W(\mathrm{I})}\left(Y_{(-)}, M Y_{(-)}, R C C G_{B V(+)}, R C C G_{E V(+)}, R V V_{C E(+)}, S_{(+/)}\right), \\
& W T D_{(\mathrm{I})}=f_{W(\mathrm{I})}\left(I F_{(+)}, M M C G_{(+)}, R A V_{B(-)}, R A V_{S S(-)}\right),
\end{aligned}
$$

where $Y$ is income, $M Y$ is missing income, $R C C G_{B V}$ is the bequest value as a reason for protecting cultural goods in general, $R C C G_{E V}$ is the existence value as a reason for protecting cultural goods, $R V V_{C E}$ are cultural events as a reason for visiting Venice, $\mathrm{S}$ is a vector of social variables such as education and age, ${ }^{11}$ $I F$ is in favour, $M M C G$ is believing in more protection for cultural goods, $R A V_{B}$ is recreational activity in Venice travelling by boat, $R A V_{S S}$ is sightseeing as a recreational activity in Venice. For non-Italian Europeans

$$
\begin{aligned}
& P W T D_{(\mathrm{NIE})}=f_{P W(\mathrm{NIE})}\left(I F_{(+)}, M M C G_{(+)}, R A V_{S S(+)}, R V V_{W S(+)}, C_{(+)}, H_{(+)}, I P T_{(+)}\right), \\
& W T D_{(\mathrm{NIE})}=f_{W(\mathrm{NIE})}\left(Y_{(+)}, D M_{B V(+)}, R V V_{W S(-)}, M R_{(+)}\right)
\end{aligned}
$$

where $R V V_{W S}$ is work or study as a reason for visiting Venice, $C$ is staying on camp-sites, $H$ is staying in hotels, IPT is improving public transport to Venice and $D M_{B V}$ is the bequest value as a donation motive. For non-Europeans

$$
\begin{aligned}
& P W T D_{(\mathrm{NE})}=f_{P W(\mathrm{NE})}\left(M Y_{(-)}, R C C G_{O P(-)}, M M C G_{(+)}, M M N_{(-)}, R A V_{C G(+)},\right. \\
& \left.\quad R A V_{S S(+)}, H_{(+)}\right), \\
& W T D_{(\mathrm{NE})}=f_{W(\mathrm{NE})}\left(Y_{(+)}, H_{(+)}\right),
\end{aligned}
$$

where $R C C G_{O P}$ is the option value as a reason for protecting cultural goods and $M M N$ is believing in more money for protecting nature.

The mean WTDs, dated 2002 and indexed 2010, estimated through these models are presented in Table 13. By comparing these mean values with the most conservative observed mean values presented in Table 9 (column 4), we 
Table 13. Estimated mean willingness to donate (WTD) 2002 and indexed WTD $2010 .^{a}$

$\begin{array}{ccc}\text { Whole Italians } & \begin{array}{c}\text { Non-Italian } \\ \text { Europeans }\end{array} & \begin{array}{c}\text { Non- } \\ \text { Europeans }\end{array}\end{array}$

$\begin{array}{lllll}\text { Estimated Mean WTD, } 2002 & 3.08 & 3.93 & 2.45 & 3.6\end{array}$

Estimated Mean WTD, indexed 2010 (OECD) $3.70 \quad 4.62 \quad 3.00$

Note: ${ }^{a}$ Consumer Prices (MEI), OECD in Appendix A.

see that all the estimated mean WTDs are higher than the observed mean WTDs except for non-Europeans, for whom the estimated WTD and the observed WTD are equal; while all the estimated mean WTDs are lower than the observed mean WTDs presented in Table 9, columns (1), (3) and (5). Therefore, in order to be conservative, regarding the whole sample (data for 2002 ) it seems to us that $€ 2.93$ ( $€ 3.52$, indexed 2010) per year may be representative of the WTD of those who visit Venice in the summer.

\section{Conclusion}

This research shows that the vast majority of visitors are in favour of the Venice defence project, and in a hypothetical situation of scarcity of public funds are willing to contribute on a voluntary basis for its implementation, thus confirming worldwide concern for Venice's conservation. The main recreational activity in Venice is sightseeing on foot, and this confirms that Venice is seen as an open-air museum for its architectural and artistic characteristics.

Since the relevant population of Venice mainly consists of foreigners, this led us to describe visitor behaviour by distinguishing the donation model for Italians from that of foreigners, because nationals contribute to Venice's conservation through their income taxes and may also contribute through individual voluntary donations, while foreigners may only contribute through voluntary donation. By also distinguishing foreigners into non-Italian Europeans and non-Europeans, the observed data highlight that, on average, Italians and non-Europeans are willing to donate more than non-Italian Europeans. This result is also confirmed by estimated mean WTDs through regression analysis, which also shows that visitors, distinguished according to nationality, have different behavioural functions. In particular, even if economic theory claims that income is the main determinant of the WTD, for Italians their income does not determine their maximum WTD; this is an exception in the economic theory of demand. Individual attitudes mainly determine their WTD, which in particular depends on being in favour of Venice's defence project and on believing that more money should be spent on cultural goods in general. Income is, instead, a determinant of the WTD for both categories of foreigners, and its coefficient has the expected sign.

The majority of respondents willing to donate justify their donation by stating that they care for the benefit of future generations and bequest value is found to be a determinant of their WTD (whole sample). In addition, those who state bequest value as a donation motive on average state the highest WTD 
and the highest degree of certainty to donate. This result shows that intergenerational justice is part of the moral obligation of the majority of visitors willing to donate. It is an empirical confirmation of the validity of the key idea behind the sustainable development concept applied to the management of Venice as a cultural tourist site, which claims that the needs and aspirations of the present generations have to be satisfied under the constraint of guaranteeing to the future generations the possibility of satisfying their own needs and aspirations too.

\section{Endnotes}

1. Integrated coastal zone management (ICZM) is today the most effective approach for managing coastal resource issues. It recognizes the complexity and uncertainty of interactions among coastal and human systems and the diversity in values relating coastal resources.

2. LCSs are defined as 'shore-parallel low crested and submerged structures such as regularly overtopped emergent and submerged detached breakwaters'. They 'reduce the amount of wave energy reaching the shore behind them, . . . and can be designed to reduce or prevent the erosion of an existing beach or a beach fill, or to encourage natural sediment accumulation to form a new beach' (Burcharth et al, 2007, pp 3-5).

3. We highlight that we did not find sufficient research funds to have a new survey carried out by a market research firm.

4. WTP is used here in its general sense, whether the payment vehicle is coercive or voluntary.

5. We highlight that, in order to prevent the questionnaire being too long, Italian respondents are not asked whether they are aware that the Italian government is paying for the Venice defence project since in Italy this is common knowledge.

6. In particular, we assume that $U_{i}$ increases in $Q$ and $D_{i}$.

7. Official data shows that in summer the percentage of tourists is higher than the percentage of day-visitors, contrarily to the data per year which shows that day-visitors are more numerous than tourists.

8. The two stages can be also modelled jointly through the Tobit model (Tobin, 1958), according to which the same set of variables determines both the decision to donate and the maximum WTD. The Tobit model has been also estimated, but it does not provide more information than the two-stage model.

9. The two-stage model has been also estimated for: (1) the whole sample, by including dummy variables for those who are certain to donate, those who are uncertain to donate and those who do not answer the question about their degree of certainty to donate, but the first stage was found to be non-estimable; (2) the whole sample and different sub-samples according to nationality, by excluding those who are uncertain to donate, but it does not provide more information than that presented here.

10. Model IV is estimated by excluding the variable in favour, since the first stage was found to be non-estimable with this variable $(99 \%$ of non-Europeans are in favour of the project implementation). In addition, a correlation matrix of the independent variables (quantitative variables and dummies) considered here has been computed, but no correlation was found.

11. In function (15), (+/-) means that the coefficients of the variables of vector $\mathrm{S}$ have different signs.

\section{References}

Alberini, A. (1995), 'Optimal designs for discrete choice contingent valuation surveys: single-bound, double-bound, and bivariate models', Journal of Environmental Economics and Management, Vol 28, pp 287-306.

Alberini, A., Rosato, P., Longo, A., et al. (2005), 'Information and willingness to pay in a contingent valuation study: the value of S. Erasmo in the Lagoon of Venice', Journal of Environmental Planning and Management, Vol 48, No 2, pp 155-175.

Amemiya, T. (1978), 'The estimation of simultaneous equation generalized Probit model', Econometrica, Vol 46, pp 1193-1205.

Andreoni, J. (1989), 'Giving with impure altruism: application to charity and Ricardian equivalence', The Journal of Political Economy, Vol 97, No 6, pp 1447-1458. 
Arrow K., Solow, R., Portney, P.R., et al (1993), 'Report of the NOAA panel on contingent valuation. Report to the general counsel of the US National Oceanic and Atmospheric Administration, US Department of Commerce, Natural resource damage assessments under the Oil Pollution Act of 1990', Federal Register, Vol 58, No 10, pp 4601-4614.

Bamber B.R., and Khoury, G.A. (1999), 'Contingent valuation of landscape', Proceedings of the Institution of Civil Engineers - Transport, Vol 135, No 4, pp 185-194.

Baron, J. (1996), 'Rationality and invariance: response to Shuman', in Bjornstad, D.J., and Kahn, J.R., eds, The Contingent Valuation of Environmental Resources, Edward Elgar, Cheltenham, pp 145163.

Barrens, R.P., Jenkins-Smith, H., Bohara, A.K., et al (2002), 'Further investigation on voluntary contribution contingent valuation: fair share, time of contribution, and respondent uncertainty', Journal of Environmental Economics and Management, Vol 44, pp 144-168.

Burcharth, H., Hawkins, S.J., Zanuttigh, B., et al (2007), Environmental Design Guidelines for Low Crested Coastal Structures, Elsevier, Amsterdam.

Carson, T.R., Mitchell, R.C., and Conaway, M.B. (2002), 'Economic benefits to foreigners visiting Morocco accruing from the rehabilitation of the Fes Medina', in Navrud, S., and Ready, C.R., eds, Valuing Cultural Heritage, Edward Elgar, Cheltenham, pp 118-141.

Cellerino, R. (1998), Venezia Atlantide, L'impatto economico delle acque alte, Franco Angeli, Milano.

CESDOC (2008), 'Indagine sul turismo nel comune di Venezia nell'anno 2007, Arrivi e presenze dei turisti stranieri e Italiani’ (http://www.odcecvenezia.it).

CESDOC (2010), 'Indagine sul turismo nel comune di Venezia nell'anno 2009, Arrivi e presenze dei turisti stranieri e Italiani’ (http://www.odcecvenezia.it).

Champ, P.A., Bishop, R.C., Brown, T.C., et al (1997), 'Using donation mechanisms to value nonuse benefits from public goods', Journal of Environmental Economics and Management, Vol 33, pp $151-162$.

Comune di Venezia (2010), Servizio statistica e ricerca, T01 serie storica 1949-2009 del movimento turistico del Comune di Venezia (http://www.comune.venezia.it/statistica).

COSES (2003), Provincia di Venezia - Arrivi e presenze per località. Anni: 2000-2001-2002, APT di Venezia (http://www.coses.it/fondaci/f_turismo16.html).

COSES (2009), 'Turismo sostenibile a Venezia. Studio per il coordinamento delle strategie turistiche per il comune di Venezia, Rapporto 141' (http://www.coses.it/masterdoc.html).

Desvousges, W.H., Naughton, M.C., and Parsons, G.R. (1992), 'Benefit transfer: conceptual problems in estimating water quality benefits using existing studies', Water Resources Research, Vol 28, No 3, pp 675-683.

European Parliament and European Council (2002), Recommendation 2002/413/CE concerning the implementation of Integrated Coastal Zone Management in Europe.

Ghetti, A., and Batisse, M. (1983), 'The overall protection of Venice and its lagoon', Nature and Resources, Vol. XIX, No 4, pp 1-13.

Haab, T.M., and McConnell, K.E. (2002), Valuing Environmental and Natural Resources, Edward Elgar, Cheltenham.

Heckman, J.J. (1976), 'The common structure of statistical models of truncation, sample selection and limited dependent variables and a simple estimator for such models', Annals of Economic and Social Measurement, Vol 5, No 4, pp 475-492.

Heien, D., and Wessels, C. (1990), 'Demand system estimation with micro data: a censored regression approach', Journal of Business and Economic Statistics, Vol 8, No 3, pp 356-371.

Maddala, G.S. (1983), Limited-Dependent and Qualitative Variables in Econometrics, Cambridge University Press, Cambridge.

Marzetti Dall'Aste Brandolini S. (2003), 'Willingness to pay for the Defence of Venice (Italy) as World Heritage Site', DELOS final report, Economic and Social Valuation about European Coastal Sites, D28, D28/B. www.delos.unibo.it.

Marzetti Dall'Aste Brandolini S., and Disegna, M. (2009), 'Visitors' preferences about the defence of Venice from high water', in Franco, L., Tomasicchio, G.R., and Lamberti, A., eds, Proceedings of the 5th International Conference Coastal Structures, Venice (Italy), 2-4 July 2007, World Scientific, Singapore, pp 574-585.

Marzetti Dall'Aste Brandolini S. and Lamberti A. (2003), 'Economic and social valuation of the defence system of Venice and its Lagoon (Italy)', Proceedings of the Sixth International Conference on the Mediterranean Coastal Environment, MEDCOAST 03, E. Ozhan (ed.), 7-11 October 2003, pp 307-318. 
Mitchell, R.C., and Carson, R.T. (1989), 'Using surveys to value public goods: the contingent valuation method', Resources for the Future, Washington DC.

Navrud, S., and Ready, R., eds (2002), Valuing Cultural Heritage: Applying Environmental Valuation Techniques to Historic Buildings, Monuments and Artifacts, Edward Elgar, Cheltenham.

Noonan, D.S. (2003), 'Contingent valuation and cultural resources: a meta-analytic review of the literature', Journal of Cultural Economics, Vol 27, pp 159-176.

Pearce, D., Atkinson, G., and Mourato, S. (2006), Cost-Benefit Analysis and the Environment - Recent Developments, OECD Publishing, Paris.

Pearce, D., Mourato, S., Navrud, S., et al (2002), 'Review of existing studies, their policy use and future research needs', in Navrud, S., and Ready, R., eds, Valuing Cultural Heritage, Edward Elgar, Cheltenham, pp 257-270.

Polomè, P., Marzetti, S., and Van der Veen, A. (2005), 'Economic and social demands for coastal protection', Coastal Engineering, Vol 52, No 10-11, pp 819-840.

SAL.VE (2008), 'Difesa dalle acque alte. Cantieri del sistema MOSE alle bocche di porto' (http://www.salve.it/it/soluzioni/acque/f_avanzamento.htm ).

Steinberg, R. (1987), 'Voluntary donations and public expenditures', American Economic Review, Vol 77, No 1, pp 24-36.

Tobin, J. (1958), 'Estimation of relationships for limited dependent variables', Econometrica, Vol 26, pp 24-36.

White, H. (1980), 'A heteroscedasticity-consistent covariance matrix estimator and a direct test for heteroscedasticity', Econometrica, Vol 48, pp 817-838.

WTO (1995), Collection of Tourism Expenditure Statistics, Technical Manual, n.2, UNWTO Publications, Madrid.

\section{Appendix A}

OECD indexes 2010/2002

Consumer price indexes (MEI), OECD, by nationality

Index

values

$(2010 / 2002)$

OECD - Total (Australia, Austria, Belgium, Canada, Czech Republic, Denmark,

Finland, France, Germany, Greece, Hungary, Iceland, Ireland, Italy, Japan, Korea, Luxembourg, Mexico, the Netherlands, New Zealand, Norway, Poland, Portugal, Slovak Republic, Spain, Sweden, Switzerland, Turkey, UK, USA)

OECD - Europe (countries in EU15 plus the Czech Republic, Hungary, Iceland,

Norway, Poland, Slovak Republic, Switzerland, Turkey)

OECD - Italy

OECD - UK

1.20

OECD - USA

1.21

OECD - Germany

1.13

OECD - France

1.14

Source: OECD, http://stats.oecd.org/index.aspx?datasetcode=mei_prices. 
List of independent variables

\begin{tabular}{|c|c|c|}
\hline $\begin{array}{l}\text { Independent } \\
\text { variables }\end{array}$ & Definitions & $\begin{array}{c}\text { Whole } \\
\text { sample } \\
(\%)\end{array}$ \\
\hline Italians & $1=$ being Italian; $0=$ otherwise & 24.2 \\
\hline Non-Italian Europeans & $1=$ being European but non-Italian; $0=$ otherwise & 54.8 \\
\hline Non-Europeans & $1=$ being non-European; $0=$ otherwise (reference category) & 21.0 \\
\hline Tourist & $1=$ being a tourist $; 0=$ otherwise & 55.7 \\
\hline Hotel & $1=$ staying in hotel $0=$ otherwise & 34.1 \\
\hline Camping & $1=$ staying on campsite $0=$ otherwise & 12.7 \\
\hline Other & $1=$ staying in another place; $0=$ otherwise (reference category) & 8.9 \\
\hline RVV: holiday & $1=$ holiday as reason for visiting Venice; $0=$ otherwise & 85.6 \\
\hline RVV: work/study & $1=$ work as reason for visiting Venice; $0=$ otherwise & 4.6 \\
\hline RVV: cultural events & $1=$ cultural events as reason for visiting Venice; $0=$ otherwise & 6.4 \\
\hline RVV: other reason & $\begin{array}{l}1=\text { other reason for visiting Venice; } 0=\text { otherwise (reference } \\
\text { category) }\end{array}$ & 3.4 \\
\hline RAV: sightseeing & $\begin{array}{l}1 \text { = sightseeing on foot as recreational activity in Venice; } \\
\quad 0=\text { otherwise }\end{array}$ & 65.5 \\
\hline RAV: boat & $\begin{array}{l}1=\text { going by boat (gondola) as recreational activity in } \\
\text { Venice; } 0=\text { otherwise }\end{array}$ & 7.5 \\
\hline RAV: cultural goods & $\begin{array}{l}1=\text { visiting museums, churches, etc as recreational activity in } \\
\text { Venice; } 0=\text { otherwise }\end{array}$ & 20.5 \\
\hline RAV: other activity & $\begin{array}{c}1=\text { other activity as recreational activity in Venice; } \\
\quad 0=\text { otherwise (reference category) }\end{array}$ & 6.5 \\
\hline MMN & $\begin{array}{l}1=\text { believing in more money for nature conservation in } \\
\text { general; } 0=\text { otherwise }\end{array}$ & 72.6 \\
\hline MMCG & $\begin{array}{l}1=\text { believing in more money for the conservation of cultural } \\
\text { goods in general; } 0=\text { otherwise }\end{array}$ & 66.3 \\
\hline $\begin{array}{l}\text { Improving public } \\
\text { Transport }\end{array}$ & $\begin{array}{l}1=\text { believing in improving public transport in } \\
\text { general; } 0=\text { otherwise }\end{array}$ & 60.4 \\
\hline RCCG: option value & $\begin{array}{l}1=\text { option value as reason for the conservation of cultural } \\
\text { goods; } 0=\text { otherwise }\end{array}$ & 20.7 \\
\hline RCCG: existence value & $\begin{array}{l}1=\text { existence value as reason for the conservation of cultural } \\
\text { goods; } 0=\text { otherwise }\end{array}$ & 21.9 \\
\hline RCCG: bequest value & $\begin{array}{l}1=\text { bequest value as reason for the conservation of cultural } \\
\text { goods; } 0=\text { otherwise }\end{array}$ & 47.5 \\
\hline RCCG: good cause & $\begin{array}{l}1=\text { good cause as reason for the conservation of cultural } \\
\text { goods; } 0=\text { otherwise (reference category) }\end{array}$ & 10.0 \\
\hline VOCG: in Italy & $1=$ visiting other cultural cities in Italy $0=$ otherwise & 85.1 \\
\hline VOCG: abroad & $1=$ visiting other cultural cities abroad; $0=$ otherwise & 93.0 \\
\hline Member & $\begin{array}{l}1=\text { being a member of an association for the cultural goods } \\
\text { conservation; } 0=\text { otherwise }\end{array}$ & 9.8 \\
\hline In favour & $1=$ being in favour of Venice defence project; $0=$ otherwise & 93.0 \\
\hline DM: altruism & $1=$ altruism as donation motive; $0=$ otherwise & 8.7 \\
\hline DM: bequest value & $1=$ bequest value as donation motive; $0=$ otherwise & 38.2 \\
\hline DM: existence value & $1=$ existence value as donation motive; $0=$ otherwise & 7.5 \\
\hline
\end{tabular}


List of independent variables continued

Independent

variables

\section{Definitions}

Whole

sample

(\%)

DM: option value

1 = option value as donation motive; $0=$ otherwise

DM: other motive

1 = other motive as donation motive; $0=$ otherwise (reference category)

1 = being single (unmarried); 0 = otherwise

Single

1 = having attended primary and secondary schools only; 0 = otherwise (reference category)

Primary and secondary schools

1 = having a higher education; 0 = otherwise

12.1

Higher education

$1=$ having a university degree; $0=$ otherwise

43.4

44.3

$1=$ being manager/ self-employed; 0 = otherwise

43.2

1 = being an office worker/teacher/labourer; 0 = otherwise

31.0

Office worker

1 = being a housewife/ pensioner/ unemployed/student; $0=$ otherwise (reference category)

$1=18-30$ years old; $0=$ otherwise

35.4

$1=31-40$ years old; $0=$ otherwise

16.6

$1=41-50$ years old; $0=$ otherwise

26.8

$1=51$ years old and over; $0=$ otherwise (reference category)

21.2

1 = respondents do not state their income category;

$$
0 \text { = otherwise }
$$

The mid-point of each income category is considered; 0 if respondents do not state their income category

58.4 Inverse Mill's ratio

Note: ${ }^{a}$ We highlight that this reference category has been created due to the low number of observations of housewives, pensioners, students and unemployed people in the sample. 